\title{
Using the Twentieth Century Reanalysis to assess climate variability for the European wind industry
}

\author{
Philip E. Bett ${ }^{1} \cdot$ Hazel E. Thornton ${ }^{1} \cdot$ Robin T. Clark ${ }^{1}$
}

Received: 18 September 2014 / Accepted: 24 July 2015 / Published online: 5 September 2015

(c) Crown Copyright, Met Office 2015

\begin{abstract}
We characterise the long-term variability of European near-surface wind speeds using 142 years of data from the Twentieth Century Reanalysis (20CR), and consider the potential of such long-baseline climate data sets for wind energy applications. The low resolution of the 20CR would severely restrict its use on its own for wind farm site-screening. We therefore perform a simple statistical calibration to link it to the higher-resolution ERA-Interim data set (ERAI), such that the adjusted 20CR data has the same wind speed distribution at each location as ERAI during their common period. Using this corrected 20CR data set, wind speeds and variability are characterised in terms of the long-term mean, standard deviation and corresponding trends. Many regions of interest show extremely weak trends on century timescales, but contain large multidecadal variability. Since reanalyses such as ERAI are often used to provide the background climatology for wind farm site assessments, but contain only a few decades of data, our results can be used as a way of incorporating decadalscale wind climate variability into such studies, allowing investment risks for wind farms to be reduced.
\end{abstract}

Electronic supplementary material The online version of this article (doi:10.1007/s00704-015-1591-y) contains supplementary material, which is available to authorized users.

Philip E. Bett

philip.bett@metoffice.gov.uk

1 Met Office Hadley Centre, FitzRoy Road, Exeter EX1 3PB, UK

\section{Introduction}

Wind is a highly variable phenomenon over all time scales, from gusts lasting seconds, to long-period variations spanning decades (e.g. Watson, 2014). Harnessing the wind resource for electricity production is a rapidly-developing field, with many challenges for engineering, energy systems design, national-scale energy policy and meteorological forecast systems (e.g. Wiser et al, 2011) Short-term wind variability is critically important to the day-to-day management of a wind farm, and efficient running depends on having high quality wind speed forecasts (e.g. Foley et al. 2012; Jung and Broadwater, 2014). However, the impact of long-term, decadal-scale variations in the wind climate is less well understood.

This is partly due to a historical lack of data. Typically, when a site is considered for wind farm development, developers are often restricted to using statistical techniques to relate observational records from nearby stations to the site in question. Homogeneous data from any single station will usually only span a few years to a decade, but can be supplemented by data from a dedicated meteorological mast positioned on-site for a limited period of time such as 1-3 years (Petersen and Troen 2012; Liléo et al. 2013; Carta et al. 2013). In the absence of long-term data sets of wind speed itself, studies of long-term wind variability typically use pressure-based metrics as proxies for the wind (e.g. Palutikof et al, 1992), often combined with complex statistical procedures to relate to the wind speed at a site (e.g. Kirchner-Bossi et al. 2013, 2014). Around Europe, indices based on the North Atlantic Oscillation (NAO) have often been used Boccard (2009). Standard NAO indices correlate well with winter wind speeds in northern/western parts of Europe. However, this is not true more generally, such as at other times of the year or in other locations 
(Hurrell et al. 2003), and alternative indices must be used in these cases (e.g. Folland et al. 2009). Regardless of definition, the NAO does not capture the full variability seen in wind speeds. Thus, there is scope for improvement over all these techniques.

Within the past decade, reanalysis data products have been able to extend such site assessment studies, allowing a description of a reasonable climatological period of around 30 years. The two main global reanalysis data sets used for this are the ECMWF $F^{1}$ Re-Analysis Interim product (ERA-Interim, hereafter ERAI; Dee et al. 2011), and NASA's Modern Era Retrospective-analysis for Research and Applications (MERRA, Rienecker et al. 2011), which both cover the 'satellite era' (1979 onwards). Such data sets are necessarily produced at relatively low spatial resolution (e.g. grid sizes $\sim 0.7^{\circ}$ ), and cannot, on their own, be used to determine the likely wind speeds at a site. In combination with other techniques however, from simple rescaling, detailed statistical modelling or even full dynamical downscaling, reanalysis data can be a key source for obtaining a representative wind climatology for a specific site (Kiss et al. 2009; Petersen and Troen 2012; Kubik et al. 2013; Badger et al. 2014).

Most recently, attempts at producing century-scale reanalyses have yielded results: the NOAA ${ }^{2}$ Twentieth Century Reanalysis (hereafter 20CR, Compo et al. 2011) and ECMWF's ERA-20C (Poli et al. 2013; Dee et al. 2013) data sets provide ensemble realisations of the atmospheric state spanning over 100 years. However, as they are at even lower resolution (e.g. $1-2^{\circ}$ ), and their early data is subject to substantial uncertainty, care must be taken when considering how to interpret their results in the context of wind farms.

Concerns within the wind industry about the possible impacts of future climate change, along with greater availability of larger data sets, have motivated various studies resulting in a greater awareness of the risks of climate variability (whether anthropogenic or natural). In fact, unlike the situation for temperature, there is little evidence of any long-term trend in globally-averaged wind speeds-see, e.g. the Fourth and Fifth Assessment Reports (AR4/AR5 respectively) of the IPCC' ${ }^{3}$ Working Group I, Trenberth et al. (2007) and Hartmann et al. (2013). The low confidence in such assessments is due in part to difficulties with the historical observational record, coupled with the highly-variable nature of winds in both space and time. For example, various data sets have suggested a positive trend in wind speeds over the oceans, with significant regional variability (Tokinaga and Xie 2011; Young et al. 2011b; Young et al. 2011a; Wentz and Ricciardulli 2011; Young et al. 2012). Over land

\footnotetext{
${ }^{1}$ European Centre for Medium-range Weather Forecasting

${ }^{2}$ National Oceanic and Atmosphere Administration

${ }^{3}$ Intergovernmental Panel on Climate Change
}

however, the situation is different: an apparent reduction in surface wind speeds (nicknamed 'global stilling') has been seen in recent decades in some data sets (McVicar et al. 2012, 2013), with studies suggesting that it could be due in part to anthropogenic factors, such as changes in land-use increasing the surface roughness (Vautard et al. 2010; Wever 2012), or aerosol emissions locally changing the thermal structure of the atmosphere (Bichet et al. 2012). It is important to note that stilling is not seen in reanalysis data, which use climatological aerosol levels and do not include landuse change. Over both the land and oceans, opposing trends in different regions and times of year will act to reduce any globally averaged trend signal. While further and better data is required to settle questions on the true scale, causes and interrelationships of changes in wind speeds over oceans and land, it is important to note that these observed trends are always much smaller than interannual variability.

Given the uncertainties in trends in the historical wind climate, it is not surprising that projections of future wind climates should also be treated with caution. The review of Pryor and Barthelmie (2010) concluded that wind speeds over Europe would continue to be dominated by natural variability, although by the end of the century some differences could have emerged-although even the sign of the change was uncertain. The IPCC's Special Report on Renewable Energy Sources and Climate Change Mitigation (SRREN) came to a similar conclusion (Wiser et al. 2011), and the IPCC's AR4 (Meehl et al. 2007; Christensen et al. 2007) and AR5 (Collins et al. 2013; Christensen et al. 2013) noted that there is low confidence in any projected changes. Consequently, Pryor and Schoof (2010) and Dobrynin et al. (2012) found that the choice of emission scenario or concentration pathway has relatively little impact overall on the resulting wind climate. It is important to note that simulations of the historical climate over the twentieth century (from both atmosphere-only and ocean-coupled models) do not reproduce the observed variability in atmospheric circulation (Scaife et al. 2005; Scaife et al. 2009), so the uncertainties in these climate projections do not preclude large multi-decadal variations in the future.

Overall, the effect of climate change on the annuallyaveraged wind resource is thought to be small, although the increased seasonality seen in some studies by 2100 could have a challenging impact on wind-dominated electricity networks (Hueging et al. 2012; Cradden et al. 2012).

Thus, when seeking to improve assessments of future wind speeds over the lifetime of a turbine, there is more to be gained from an increased understanding of historical long-term wind variability than through climate change model runs. Given this context, we show in this paper how the new class of century-scale reanalyses can be linked to the more widely-used satellite-era reanalyses, thus allowing for information on the long-term decadal-scale variability in wind speeds to be propagated through the model chain when performing a wind site assessment. In Section 2, we 
describe the two main data sets we use, including their limitations. We compare them in detail in Section 3, and describe our procedure for relating the two. Section 4 shows results for the wind speed distribution over Europe, including long-term averages, variabilities and changes in the shape of the distribution over time for selected regions. We discuss our conclusions in Section 5.

\section{Data sources}

Reanalyses represent the most convenient data sets for assessing the long-term historical wind climate, in the sense that they aim to provide an optimal combination of observations and numerical model: the data provided in a reanalysis aims to give the best estimate of the "true" situation at any given point, as well as being homogeneous in time (e.g. free of systematic shifts), and complete in both space and time. However, in reality, biases and uncertainties inherent in both raw observations (due to location, frequency, instrumentation, etc.) and models (due to resolution, parametrisation schemes, etc.) mean that such data sets must be used with caution.

This study primarily uses data from the Twentieth Century Reanalysis project (20CR), in conjunction with wind speeds from the ERA-Interim data set (ERAI) for validation and calibration of the 20CR data. We describe key aspects of these data sets in the following sections.

\subsection{Data from the 20CR ensemble system}

A full description of the ensemble reanalysis system used in the 20CR project is given in Compo et al. (2011). Here, we describe some key features that have important impacts on our analysis methods and results.

The 20CR assimilates sea-level pressure and surface pressure observations alone (from the International Surface Pressure Databank, incorporating the $\mathrm{ACRE}^{4}$ project, Allan et al. 2011), using observational fields of sea-surface temperature and sea-ice concentration (HadISST1.1, Rayner et al. 2003) as boundary conditions. It uses the April 2008 experimental version of the NCEP ${ }^{5}$ Global Forecast System (GFS), a coupled atmosphere-land model produced by the NOAA NCEP Environmental Modelling Centre.

The 20CR data assimilation system is based on an Ensemble Kalman Filter. The data are produced in a series of 5-year ' 'streams' (independent runs, to simplify parallelisation), with 56 members in each stream. A consequence of

\footnotetext{
${ }^{4}$ Atmospheric Circulation Reconstructions over the Earth, http://www. met-acre.org/

${ }^{5}$ National Centres for Environmental Prediction

${ }^{6}$ Streams 16 and 17 actually last 6 and 4 years respectively (see Table III in Compo et al. 2011). For simplicity, we assume 5-year streams throughout.
}

this system is that ensemble members only remain temporally continuous for the 5-year duration of each stream. This has implications for how variability is assessed over long time periods; we discuss this in more detail in Section 4.1.

As highlighted in Compo et al. (2011), when considering variability, it is important to use the ensemble members directly, rather than using the daily ensemble-mean time series alone. The increased uncertainty in the early period of the data leads to greater disagreement between the ensemble members, such that a time series of their mean will have much less variability than the members individually. This would lead to a spurious strong reduction in variability appearing at earlier times in the ensemble mean.

We use the updated release of the 20CRv2 data (hereafter simply 20CR), spanning 142 years from 1st Jan 1871 to 31 st Dec 2012. While it was produced on a T62 spectral grid with 28 vertical levels, we use the output data provided on a regular latitude-longitude grid with cell size $2^{\circ}$, at the the near-surface pressure level at $\sigma:=$ $P / P_{\text {surface }}=0.995$ (around $40 \mathrm{~m}$ height). The $\sigma=0.995$ level is a reasonable choice for turbines whose rotor hubs are expected to be some tens of metres above the surface; typical hub heights are between 40 and $100 \mathrm{~m}$, but vary greatly (Wiser et al. 2011); we do not expect our conclusions to be qualitatively affected by the precise height above ground. More details on our choice of levels can be found in Appendix A. We use daily-mean wind speeds $U$, which we calculate by averaging the wind speed magnitudes from the 6-hourly $u$ (zonal, i.e. westerly) and $v$ (meridional, i.e. southerly) component fields. We are not considering subdaily variability, as this is likely to be poorly represented with only four timesteps per day, in addition to the low horizontal resolution. Using daily means significantly reduces the amount of data that we need to analyse. However, calculating daily means using only four snapshots is likely to lead to some underestimation, as the wind distributions we are sampling tend to be positively skewed. Using daily means also has an impact on the form of the resulting wind speed distribution, and on Weibull fits in particular; we discuss this in the Supplementary Information.

Some recent studies have highlighted potential problems with the 20CR data set. Ferguson and Villarini $(2012,2014)$ have performed a detailed analysis of change points in the 20CR data, finding that, while these are in fact common in the data set overall, there are many areas, especially in the northern hemisphere, where the 20CR remains largely homogeneous for many decades. Their results emphasize that users of the 20CR data must be aware of possibleindeed, probable - inhomogeneities in the data, and the potential impact this could have on their analyses. Stickler and Brönnimann (2011) found very significant differences between 20CR winds and pilot balloon measurements in the West African Monsoon region over 1940-1957, and 
Liléo et al. (2013), using the 20CR to study interannual wind variability over Scandinavia, had to discard 20CR data prior to 1920 due to suspicious behaviour in some grid cells. Finally, there has been some debate on the consistency of long-term trends in storminess and extreme winds found in 20CR compared to observations (Donat et al 2011, Brönnimann et al 2012, Wang et al. 2013, 2014), and Krueger et al. $(2014,2013)$. These studies serve to emphasize the importance of being extremely careful with methodology when comparing reanalysis data with observations, and when identifying trends.

\subsection{Data from ERA-Interim}

The second source of data we use is the $60 \mathrm{~m}$ wind speed fields from the ERAI data set (Dee et al. 2011). This uses the ECMWF Integrated Forecasting System model (IFS), and assimilates observational data of many types, mostly coming from satellites. The atmospheric fields of ERA-Interim were calculated on a T255 spectral grid, with surface fields calculated on a reduced Gaussian grid. We use the 6-hourly wind speed data available on the regular latitudelongitude grid of cell-size $0.75^{\circ}$, and calculate daily-mean wind speeds as for the 20CR. A comparison of ERAI data at 60 and $10 \mathrm{~m}$ with the 20CR levels can be found in Appendix A. The reanalysis starts in 1979 and continues to the present; we use the data up to the end of 2013. Further details are available in Dee et al. (2011) and references therein, and the ERA-Interim Archive report (Berrisford et al. 2011).

Stopa and Cheung (2014) compared ERAI wind speeds with those measured from buoys and satellite data, finding that the reanalysis performs very well in terms of homogeneity, but with a small negative bias and reduced variability compared to the observations. Szczypta et al. (2011) found that ERA-Interim tended to overestimate wind speeds over most of France, but underestimated it in mountainous areas, compared to the SAFRAN high resolution $(8 \mathrm{~km})$ reanalysis data set-although the authors note that the SAFRAN wind speed data is known to be biased low.

As already discussed, it is known that reanalysis data sets including ERA-Interim do not exhibit the observed largescale trends in wind speeds (see, e.g. McVicar et al. 2013, Mears 2012 and references therein), and the relatively low resolution of ERAI (and similar data sets) prevents it from being used directly as a proxy for observations at the scale of a wind farm (Kiss et al. 2009; Kubik et al. 2013). We will instead be using ERAI as an example of the kind of data currently used for providing a climatological basis for wind farm site assessments, the first link in the 'model chain' of dynamical and statistical downscaling for such studies: reanalyses are connected to mesoscale dynamical models, then in turn to microscale models and computational fluid dynamics (CFD) at the scale of a wind farm itself (Petersen and Troen 2012).

\section{Linking the reanalyses}

While the strength of the 20CR is its characterisation of realworld variability on long time scales, the ERA-Interim data set provides wind speeds that are at much higher spatial resolution, and are more tightly-constrained by observations. ERA-Interim is therefore much better suited for developing a climatology of wind speeds over small (sub-national) regions, or, in conjunction with additional dynamical or statistical downscaling techniques, at a point location. However, as it only spans $\sim 30$ years, it cannot give a good indication of climate variability on multi-decadal timescales. In this section, we describe how we calibrate the 20CR wind speed data to produce a data set that has the same distribution of wind speeds in time as ERA-Interim (over their overlapping period), but with the long-term variability of 20CR.

\subsection{Comparison of the reanalyses}

We focus our study on Europe, and consider several small sub-regions for more detailed examination. To aid comparison, we regrid the ERAI data by area-averaging onto the 20CR's native $2^{\circ}$ grid.

The 20CR and ERAI data do not exhibit the same climatology in wind speeds over their period of intersection (1979-2012, 34 years). This is due to a number of factors. These include the structural differences (NWP model, data assimilation and reanalysis procedure), spatial resolution and the amount of orographic complexity resolved, the amount and type of observational data assimilated and the mismatch between vertical levels available for comparison.

In this section, we denote ensemble-mean daily-mean wind speeds from 20CR (at its $\sigma=0.995$ vertical level) and from ERAI (at its $60 \mathrm{~m}$ model level on the 20CR grid), by $U^{20 C R}$ and $U^{\text {ERAI }}$ respectively. As we are focusing on the later period of the $20 \mathrm{CR}$ data set for our calibration procedure, the ensemble spread is small, so it is acceptable to use the ensemble mean series in this case (this is not generally true for all time periods, or regions of the globe with fewer observations; see Compo et al. 2011). We consider the 'bias' between the 20CR and ERAI data in terms of the simple difference in wind speeds,

$\beta:=U^{20 \mathrm{CR}}-U^{\mathrm{ERAI}}$,

and the day-to-day relative difference compared to ERAI,

$\beta_{\text {rel }}:=\left(U^{20 \mathrm{CR}}-U^{\mathrm{ERAI}}\right) / U^{\mathrm{ERAI}}$. 
In Fig. 1 , we show ${ }^{7}$ the 34 -year mean bias $\langle\beta\rangle$ and the mean of the day-to-day relative bias $\left\langle\beta_{\text {rel }}\right\rangle$. The bias maps are all rather noisy, but over most of the land surface the bias is negative (i.e. $U^{20 \mathrm{CR}}<U^{\mathrm{ERAI}}$ ), with differences of up to $\sim 20 \%$ of the ERAI wind speeds in many areas. There are some notable exceptions to this however, with positive biases (i.e. $U^{20 \mathrm{CR}}>U^{\mathrm{ERAI}}$ ): for example over Britain, wind speeds are up to $20 \%$ higher in the 20CR data. Some areas have particularly strong negative bias, such as around the Czech Republic. The Strait of Gibraltar is particularly affected by the low spatial resolution, resulting in the lowest 20CR wind speeds compared to ERAI. We have used a $t$ test to assess whether the data is consistent with $\langle\beta\rangle=0$ (i.e. no bias) at the $1 \%$ level. When it is not consistent with zero, we say there is a significant bias; this is the case for most areas according to this test.

In addition to the spatial variability, it is important to bear in mind that the difference between 20CR and ERAI does not have to be constant in time. Figure 2 shows the day-to day variability of $\beta_{\text {rel }}$ in terms of its standard deviation $\sigma$. There is a suggestion in the data of increased $\beta_{\text {rel }}$ around coastal regions, such as in large parts of the Mediterranean, as well as Norway and Britain. The relativebias variability is generally around $15-30 \%$, which is a similar magnitude to the mean relative bias $\left\langle\beta_{\text {rel }}\right\rangle$ shown in Fig. 1.

Finally, we show the correlation between the daily wind speeds of the 20CR and ERAI in Fig. 3. The data are well-correlated in most places, but the correlation is particularly strong $(\geq 0.9)$ in the Atlantic and northern Europe, including the British Isles.

\subsection{Procedure for calibration}

The goal of our calibration procedure is to generate a wind speed data set that retains the fluctuation patterns of the 20CR data over time, and between ensemble members, but whose probability density functions (PDFs) of the ensemble-mean wind speed in each grid cell match those of the ERA-Interim data during their overlapping time period. In particular, the PDFs do not have to match over other periods (e.g. if comparing the distribution over 142 years from 20CR to the 35 years from ERAI), the time series do not have to match in detail (although we have shown that they do tend to be well-correlated), and individual

\footnotetext{
${ }^{7}$ Throughout this paper, we present maps on the 20CR's $2^{\circ}$ grid in a Lambert Azimuthal Equal-Area projection centred on $\left(10^{\circ} \mathrm{E}, 52^{\circ} \mathrm{N}\right)$, following, e.g. Annoni et al. (2003), code EPSG::3035. Calculations are performed on the regular lat.-lon. grid.
}

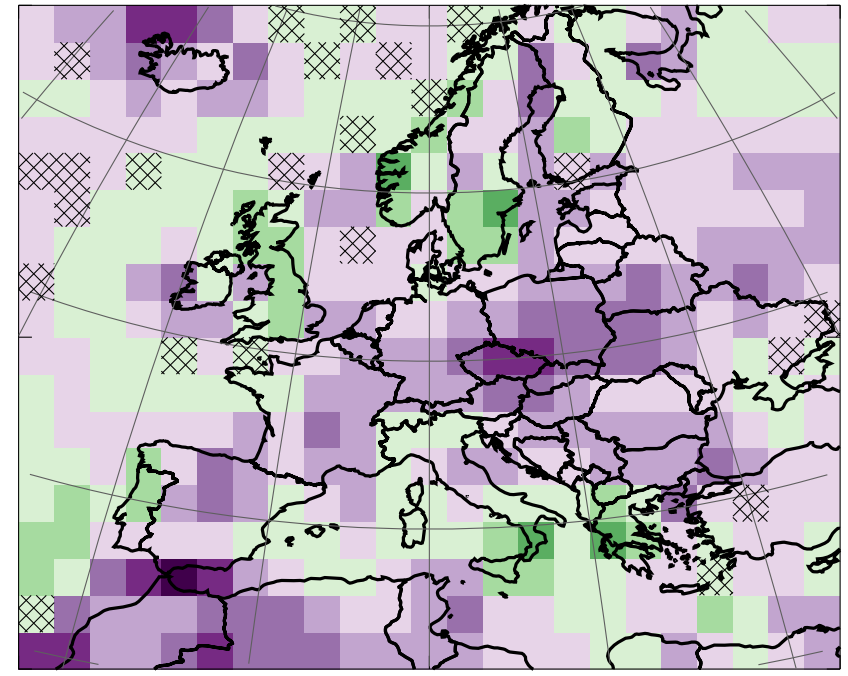

Mean difference of daily wind speeds, $\langle\beta\rangle=\left\langle U^{20 \mathrm{CR}}-U^{\mathrm{ERAI}}\right\rangle, \mathrm{m} \mathrm{s}^{-1}$
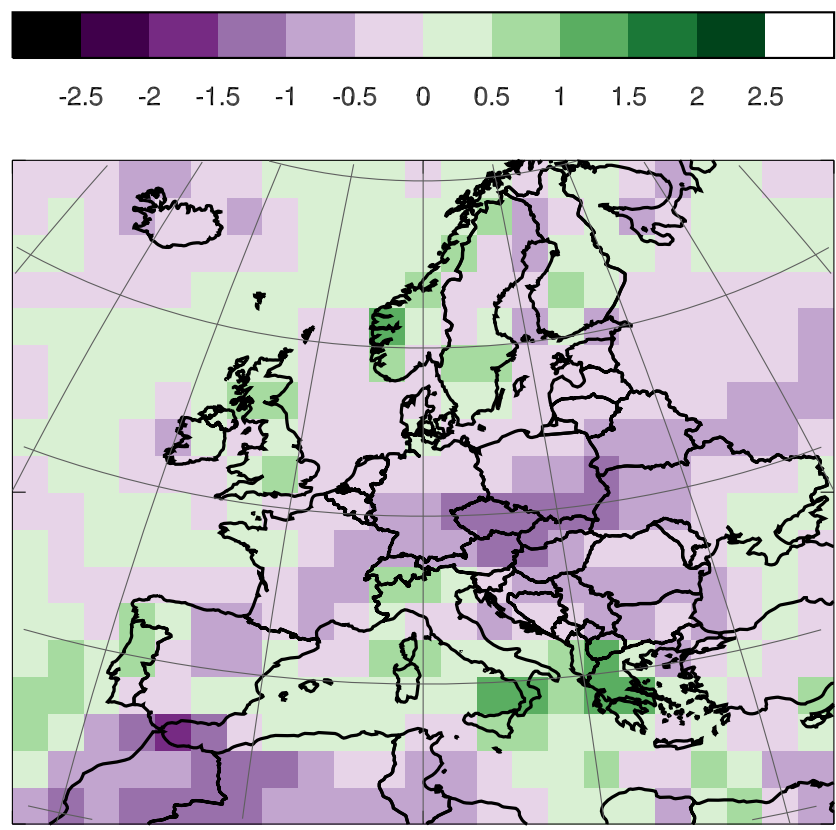

Mean relative diff. of daily wind speeds, $\left\langle\beta_{\text {rel }}\right\rangle=\left\langle\left(U^{20 \mathrm{CR}}-U^{\mathrm{ERAl}}\right) / U^{\mathrm{ERAl}}\right\rangle$

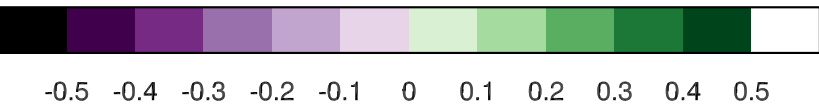

Fig. 1 Maps of the difference between wind speeds from 20CR and ERA-Interim; details as given in the panels. Crosshatched areas in the top panel are not significantly different from zero at the $1 \%$ level, according to a $t$ test

ensemble members do not need to match ERAI data-thus retaining the 20CR's important measure of uncertainty. We illustrate our procedure for the case of a particular grid cell in Fig. 4.

Our method proceeds in two stages, and is performed on each grid cell independently. Firstly, a transfer matrix 


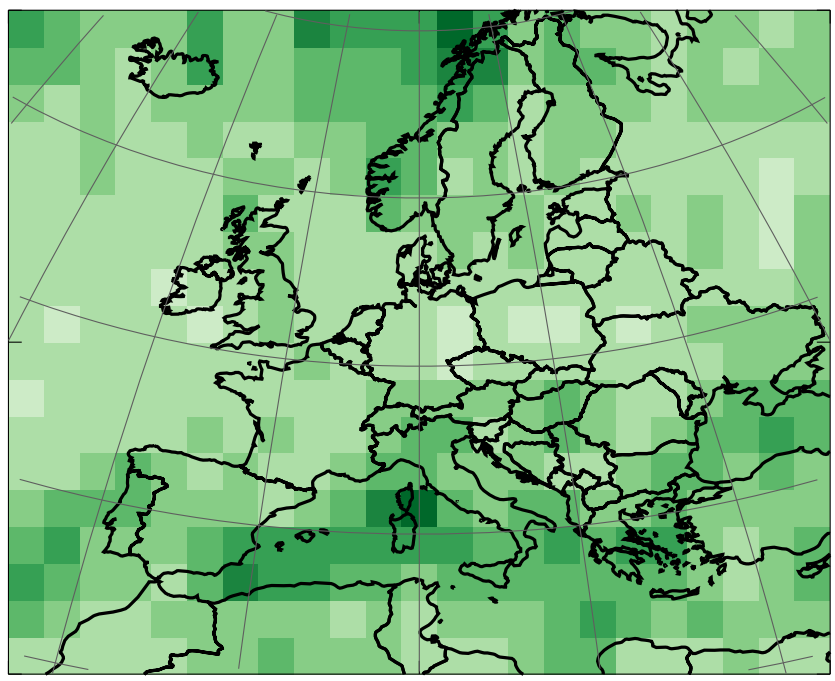

Variability of daily wind speeds bias, $\sigma\left(\left[U^{20 \mathrm{CR}}-U^{\mathrm{ERAl}}\right] / U^{\mathrm{ERAl}}\right)$

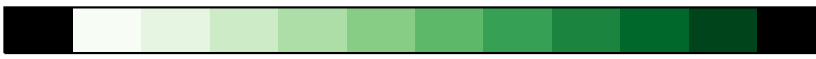

$\begin{array}{lllllllllll}0 & 0.05 & 0.1 & 0.15 & 0.2 & 0.25 & 0.3 & 0.35 & 0.4 & 0.45 & 0.5\end{array}$

Fig. 2 Map of the variability of the daily relative 'bias' $\beta_{\text {rel }}$ between 20CR and ERAI wind speeds, in terms of its standard deviation

is obtained as the conditional probability density of ERAI wind speeds, given bins of 20CR ensemble mean, daily mean wind speeds for the overlapping period:

$\mathcal{P}_{i j}:=P\left(U_{i}^{\mathrm{ERAI}} \mid U_{j}^{20 \mathrm{CR}}\right)$,

where $i$ and $j$ index bins in wind speed for the data sets indicated. We use bins of $0.5 \mathrm{~m} \mathrm{~s}^{-1}$ covering the range 0 $40 \mathrm{~m} \mathrm{~s}^{-1}$. This transfer matrix is applied to the full 142-year 20CR PDF, to obtain a calibrated PDF of 20CR wind speeds spanning 1871-2012:

$P\left(U_{i}^{20 \mathrm{CRc}}\right)=\sum_{j} \mathcal{P}_{i j} P\left(U_{j}^{20 \mathrm{CR}}\right)$.

Secondly, calibrated daily time series of wind speeds, $U^{20 \mathrm{CRc}}(t)$, from all ensemble members, are obtained by quantile matching (e.g. Panofsky and Brier 1968): the cumulative distribution function (CDF) of the calibrated 20CR ensemble mean wind speeds is interpolated at the quantiles of each ensemble member's wind speed (see bottom-left panel in Fig. 4). Using the individual ensemble members in this step rather than the ensemble mean allows the ensemble spread to be transferred to the calibrated climatology.

In some cases, there can be wind speeds present in the 142-year 20CR data that were greater than any in the 34year period common with ERAI. This means that such wind speeds have no corresponding frequency in ERAI that we can calibrate to: the $\mathrm{CDF}$ corresponding to $P\left(U_{i}^{20 \mathrm{CRc}}\right)$

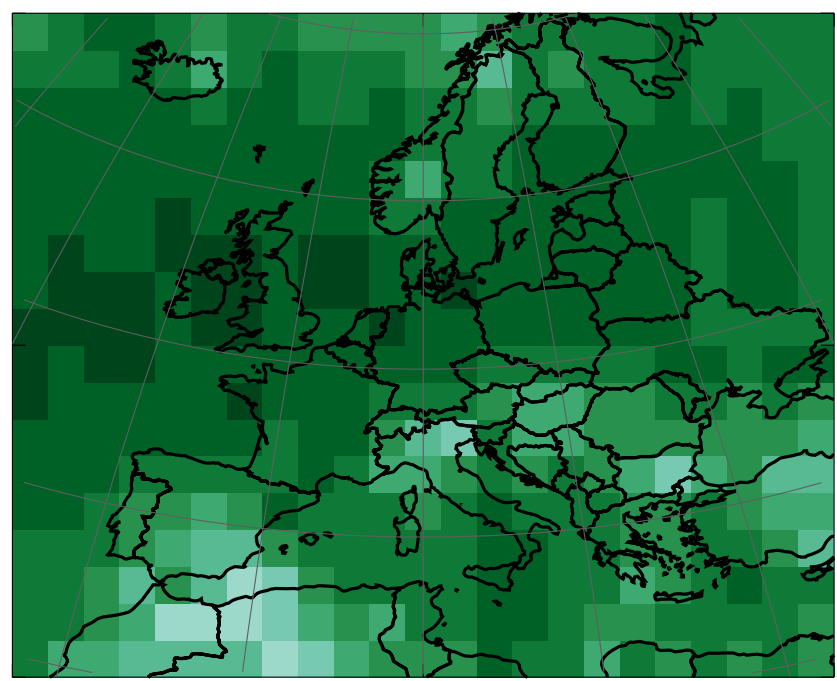

Pearson correlation between 20CR and ERAI daily wind speed

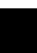

$\begin{array}{lllllllllllll}0.4 & 0.45 & 0.5 & 0.55 & 0.6 & 0.65 & 0.7 & 0.75 & 0.8 & 0.85 & 0.9 & 0.95 & 1\end{array}$

Fig. 3 Map of the Pearson correlation between daily-mean wind speeds in 20CR and ERA-Interim

reaches its maximum ${ }^{8}$ below that wind speed, so quantile matching by interpolating the CDF will fail. In this case, we instead perform a linear regression on the relationship between original and corrected winds up to this point (i.e. $\left.U^{20 \mathrm{CRc}}\left(U^{20 \mathrm{CR}}\right)=a U^{20 \mathrm{CR}}+b\right)$. We then extrapolate this model to obtain corrected wind speeds for the final few high wind days.

We demonstrate our procedure for the case of a grid cell in north-western Germany in Fig. 4. This shows the different PDFs in question, the transfer matrix and the quantile matching. It is clear that in this case the ERAI wind climate largely represents a shift to higher wind speeds compared to 20CR (i.e. the 20CR winds are low compared to ERAI), and the calibrated 20CR reproduces this well. The PDFs of both the ERAI and 20CR wind speeds appear somewhat truncated at lower wind speeds, rather than reducing smoothly towards $U=0 \mathrm{~m} \mathrm{~s}^{-1}$. This is due to the daily averaging of the 6-hourly wind speeds, and has implications when attempting to fit Weibull functions to the wind speed distribution; we discuss this issue in detail in the Supplementary Information.

It is important to note that the method we describe here is not unique. Many other techniques for calibrating one data set with another have been developed and used in

\footnotetext{
${ }^{8}$ Note that constructing the $\mathrm{CDF}$ in finite bins in wind speed, using a finite number of days, and relating the ensemble member time series to the ensemble mean distributions, means that sometimes the calibrated CDF does not quite reach unity.
} 

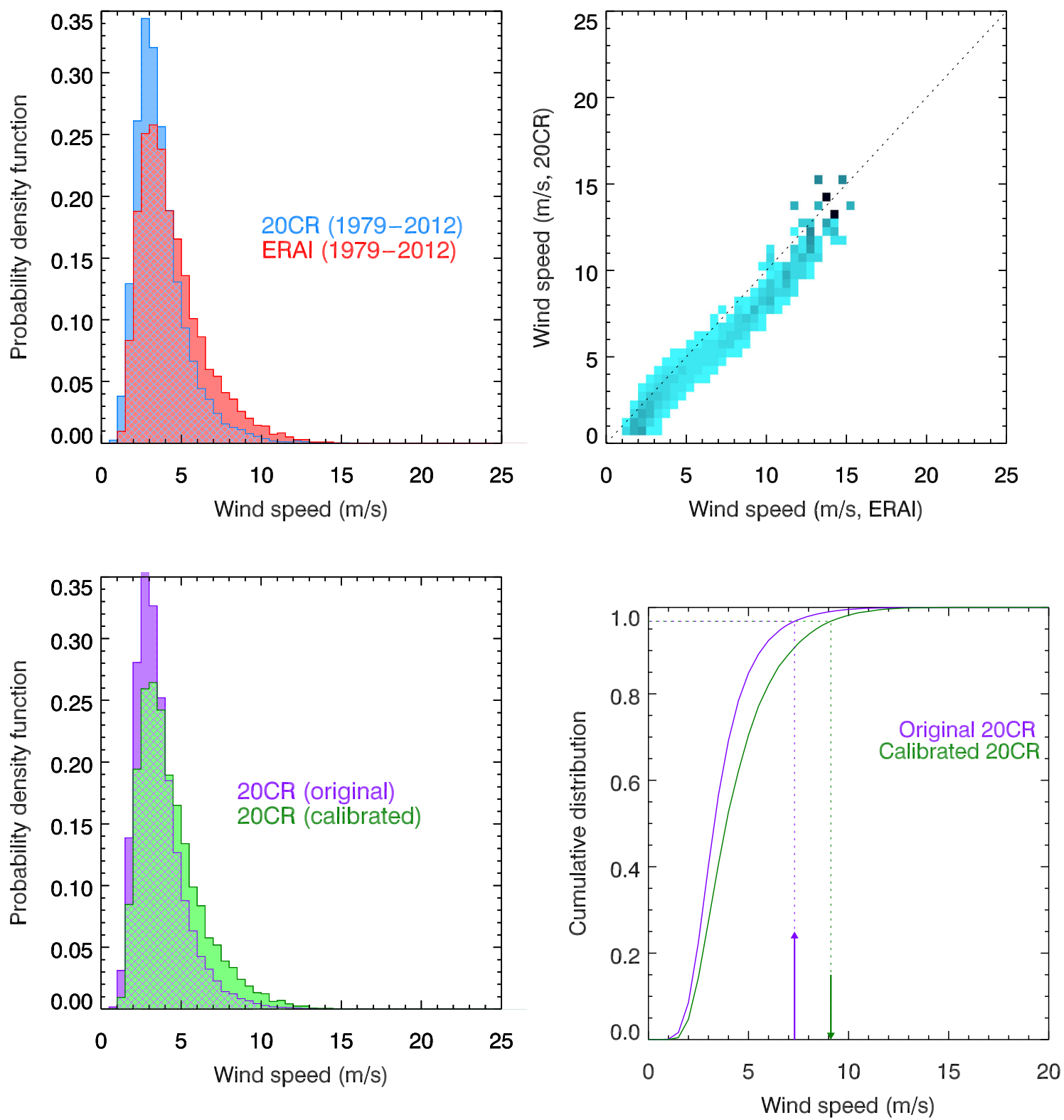

Fig. 4 Illustrating the calibration procedure, in terms of daily-mean wind speed probability distributions, for the single grid cell covering north-western Germany (centre: $8^{\circ} \mathrm{E}, 52^{\circ} \mathrm{N}$ ); for the 20CR, the ensemble mean is used throughout for clarity. Top left: Daily-mean wind speed distributions for ERAI and 20CR over their intersecting time period. Top right: A visualisation of the conditional probability matrix $P\left(U_{i}^{\mathrm{ERAI}} \mid U_{j}^{20 \mathrm{CR}}\right)$, such that each row $j$ is a PDF of ERAI wind speeds, given a particular $20 \mathrm{CR}$ wind speed $U_{j}^{20 \mathrm{CR}}$ (i.e. the values along each

row have the same sum). Darker colours indicate higher frequencies in each ERAI PDF. Bottom left: Wind speed distributions over the full 142 years. Bottom-right: The cumulative distribution function derived from the PDF histograms shown to the left. The dotted lines and arrows illustrate the interpolation in the quantile-matching procedure used to convert wind speeds from the original 20CR data to their calibrated counterparts. Here, a high wind speed for this cell from the original 20CR is transformed to its higher counterpart at the same level in the calibrated distribution

climatological studies. These are usually designed to compare reanalysis or model data with observations, or climate model data at different spatial scales, such as a global run with regional model output; see (Teutschbein and Seibert 2012), Watanabe et al. (2012), Lafon et al. (2013) and references therein for recent reviews of methods. Compromises are reached between statistical complexity, data volumes,

direct numerical simulation and time available. In our case, we have chosen a relatively simple statistical procedure.

\subsection{Results of calibration procedure}

Time series of annual mean wind speeds from both the original and calibrated 20CR data, and from ERA-Interim, 


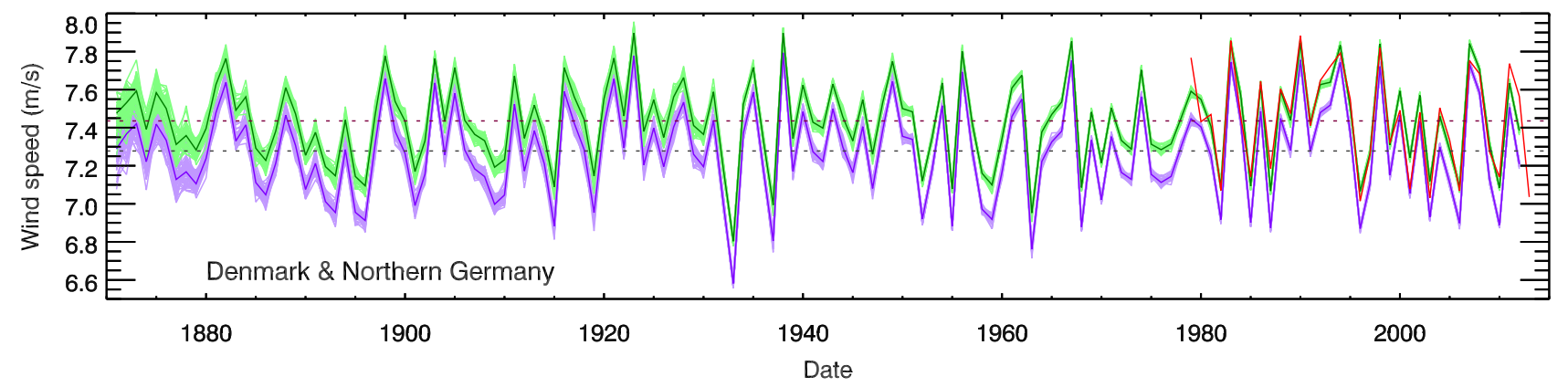

Fig. 5 Time series of annual mean wind speeds for a region covering $9^{\circ} \mathrm{E}-15^{\circ} \mathrm{E}$ and $53^{\circ} \mathrm{N}-57^{\circ} \mathrm{N}$, showing the original 20CR data (purple), ERA-Interim (red) and calibrated 20CR (green). For the 20CR

are shown in Fig. 5 for a region covering Denmark and Northern Germany (using area-weighted averaging over the region). The calibrated data retains the interannual variability of the original 20CR wind speeds, but with a climatology matching that of ERA-Interim over 1979-2012.

We map the bias remaining after our procedure in Fig. 6. This can be compared to the original bias maps in Fig. 1-note that here the values are much smaller. The mean bias $\langle\beta\rangle=\left\langle U^{20 \mathrm{CRc}}-U^{\mathrm{ERAI}}\right\rangle$ is consistent with zero almost everywhere (using a $t$ test at a $1 \%$ significance level, as before). An exception is a residual positive bias east of Gibraltar: we expect this area to be heavily affected by differences in how well the complex orography here is resolved between ERAI and 20CR. Two further exceptions occur in the central and eastern Mediterranean, which correspond to anomalies seen in other aspects of the 20CR data (see later sections), and which we discuss in more detail in Appendix $\mathrm{C}$.

The mean of the relative bias $\left\langle\beta_{\text {rel }}\right\rangle$ (not shown) is $\leq$ $5 \%$ almost everywhere. Finally, we note that the correlations between 20CR and ERAI after calibration (not shown) remain almost identical to those shown previously in Fig. 3.

\section{Analysis and results}

In this section, we use the $20 \mathrm{CRc}$ data to analyse the distribution of wind speeds over Europe in various complementary ways.

\subsection{The European context: maps of the long-term average, variability and trends}

The map of the 142-year mean wind speed in Fig. 7 gives an overview of the geographic distribution of wind speeds over Europe. There is a noticeable land-sea contrast, although it is the mountainous regions that have the lowest mean wind speed, just as is seen in the uncorrected 20CR data (Bett et al. 2013), and is inconsistent with observations. This erroneous behaviour is a known consequence of the orographic drag schemes in atmospheric models (Howard and Clark data, the ensemble members are plotted in paler colours, with the ensemble means of the annual mean data plotted in darker colours. Long-term averages are plotted as horizontal dashed lines

2007), and is particularly apparent when (as here) the orographic variability is on a much smaller horizontal scale than the model grid cells. The spatial pattern in fact agrees very well with that derived by Kiss and Jánosi (2008) from the $10 \mathrm{~m}$ wind speeds covering 1958-2002 in the ERA-40 reanalysis (Uppala et al. 2005), although since they used winds at a lower level their mean values are correspondingly smaller.

It is important to note that the wind speeds shown here apply to the particular spatial scale of this data set, which implies a certain amount of smoothing compared to values measured at a specific site. For example, Kirchner-Bossi et al. (2013) use a complex statistical procedure to relate sea-level pressure from 20CR to wind speed observations at

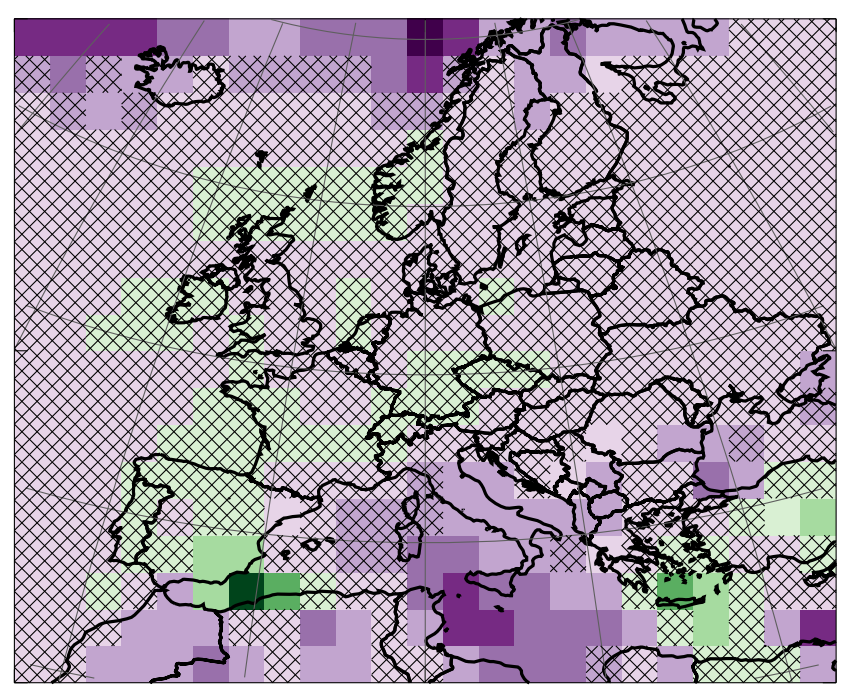

Mean diff. of daily wind speeds, $\langle\beta\rangle=\left\langle U^{20 \mathrm{CRC}}-U^{\mathrm{ERAl}}\right\rangle, \mathrm{m} \mathrm{s}^{-1}$

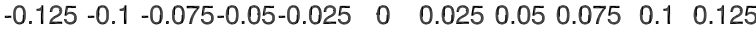

Fig. 6 Map of the remaining 'bias' after calibration. This can be compared to the map of the original bias in Fig. 1; note the colour scale covers much smaller values here. Crosshatched areas are not significantly different from zero at the $1 \%$ level, using a $t$ test 


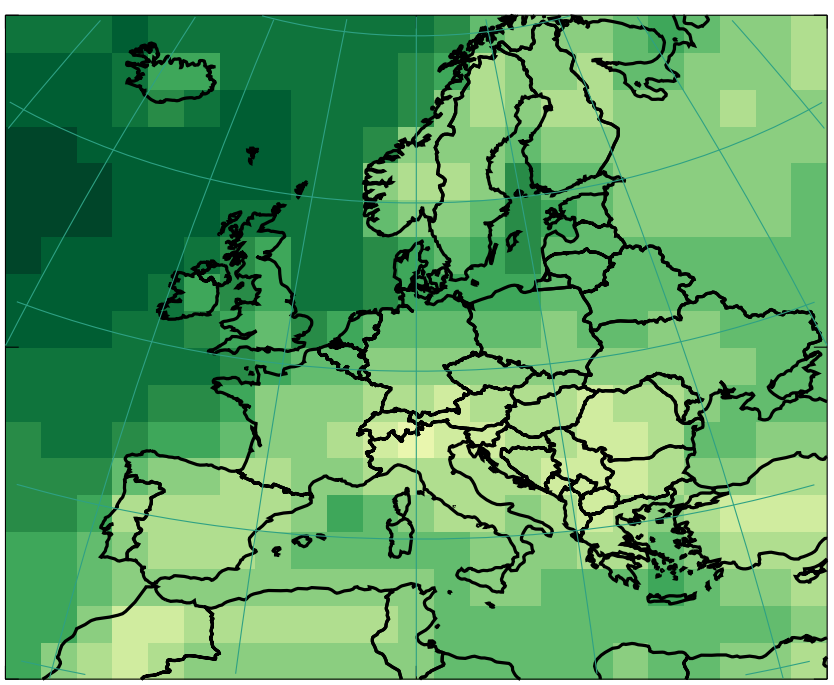

Mean daily wind speed 1871-2012 (m/s)

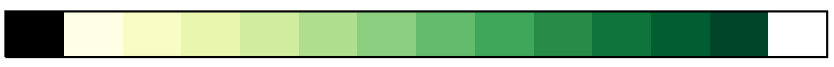

$\begin{array}{lllllllllllll}0 & 1 & 2 & 3 & 4 & 5 & 6 & 7 & 8 & 9 & 10 & 11 & 12\end{array}$

Fig. 7 Long-term mean wind speed over Europe from the 20CRc data

a range of meteorological stations in Spain. Because they are statistically downscaling to this local scale, the mean wind speed they find is $2-3 \mathrm{~m} \mathrm{~s}^{-1}$ higher than we show in Fig. 7.

We map the wind variability in terms of its standard deviation. The structure of the data set makes the calculation of the long-term standard deviation non-trivial: simply considering the ensemble-mean daily time series would result in a standard deviation that was negatively biased. Furthermore, the ensemble members' time series are only continuous in 5 -year chunks, and using them as if they were continuous throughout could potentially inflate the apparent variability at the discontinuities (although in practice the impact of this is likely to be very small). To avoid such spurious signals and trends, we calculate the mean and standard deviation of daily wind speeds in each 5-year stream for each ensemble member, then take ensemble means for each period. We then combine these 5-yearly ensemble-mean standard deviations into single aggregate values for the full 142-year period, for each grid cell; see Appendix B for details.

Since the standard deviation of wind speeds tends to correlate with the mean, we show in Fig. 8 the wind variability in terms of the coefficient of variation, the ratio of the standard deviation to the mean. This shows that, in most areas, the wind speed standard deviation is $\sim 40 \%$ of the mean. The central Mediterranean has proportionally higher variability, with Greece, Turkey and the Alps (whose orography will be extremely poorly represented) showing lower variability.

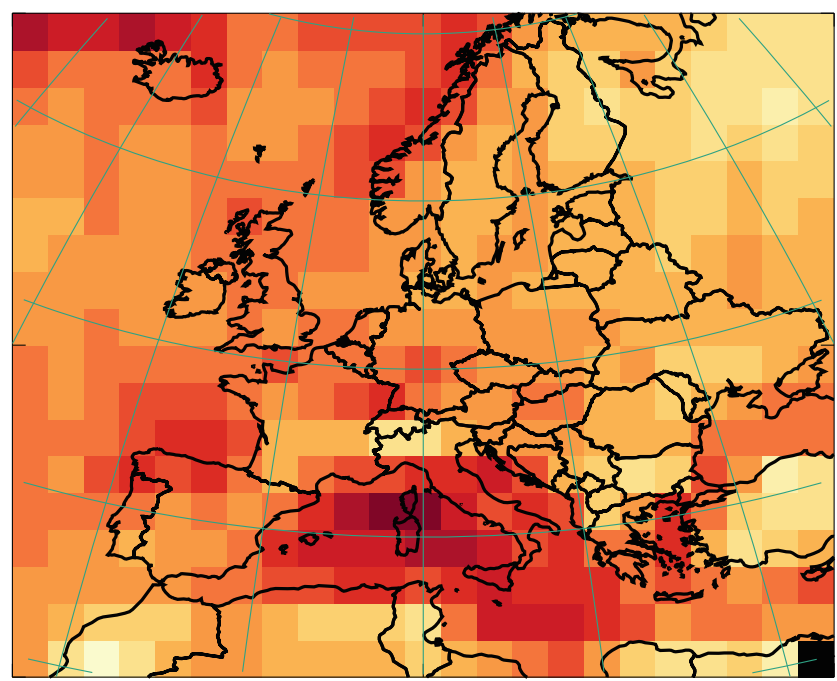

Coefficient of variation of daily wind speeds 1871-2012 (\%)

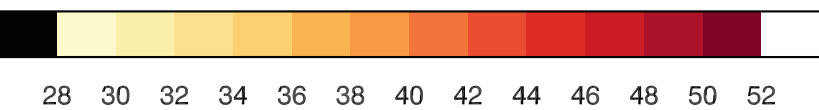

Fig. 8 Map of the wind speed variability in terms of the coefficient of variation, i.e. the ratio of the standard deviation to the long-term mean

The presence of any long-term trends in the mean or variability of wind speeds could have important consequences for wind farms, in terms of their future deployment, energy yield and maintenance requirements. Figure 9 maps the trends in both the ensemble-mean annual mean wind speed and the ensemble-mean annual standard deviation of daily wind speeds. The trends are found from the ensemblemean annual time series using the Theil-Sen estimator (Theil 1950; Sen 1968). This is the median of the slopes between all pairs of points in the data set, and is more robust against outliers than simple linear regression, making it more suited to skew-distributed data such as wind speed.

We test the significance of these trends at the $0.1 \%$ level, using a Mann-Kendall test (Mann 1945; Kendall 1975) modified using the method of Hamed and Rao (1998) to account for autocorrelation in the data (following Sousa et al. 2011); as is the case with much meteorological data, we expect adjacent timesteps to be correlated. As with all significance tests, the result says whether the measured trend was unlikely, given the assumption of there being no true underlying physical trend. If the probability of measuring the trend we did was below $0.1 \%$, then we describe the trend as 'significant', otherwise we regard it as consistent with zero. We chose the particularly stringent threshold of $0.1 \%$ to guard against detection of spurious trends; we only want to highlight trends we are very sure are present in the data.

Some key points about long-term trends in European winds are immediately apparent from Fig. 9. Firstly, they 


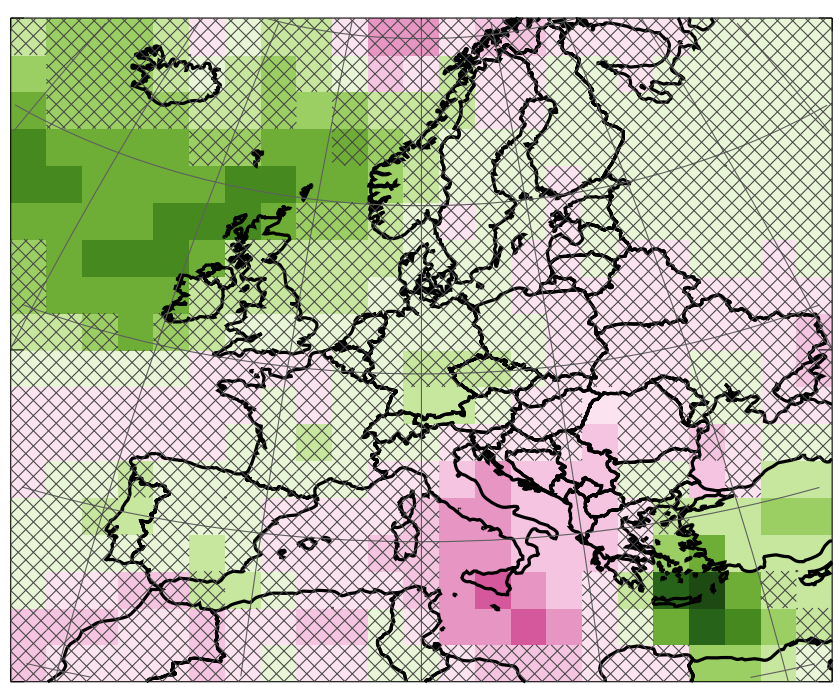

Linear trend in mean wind speed, $\mathrm{m} / \mathrm{s}$ per decade
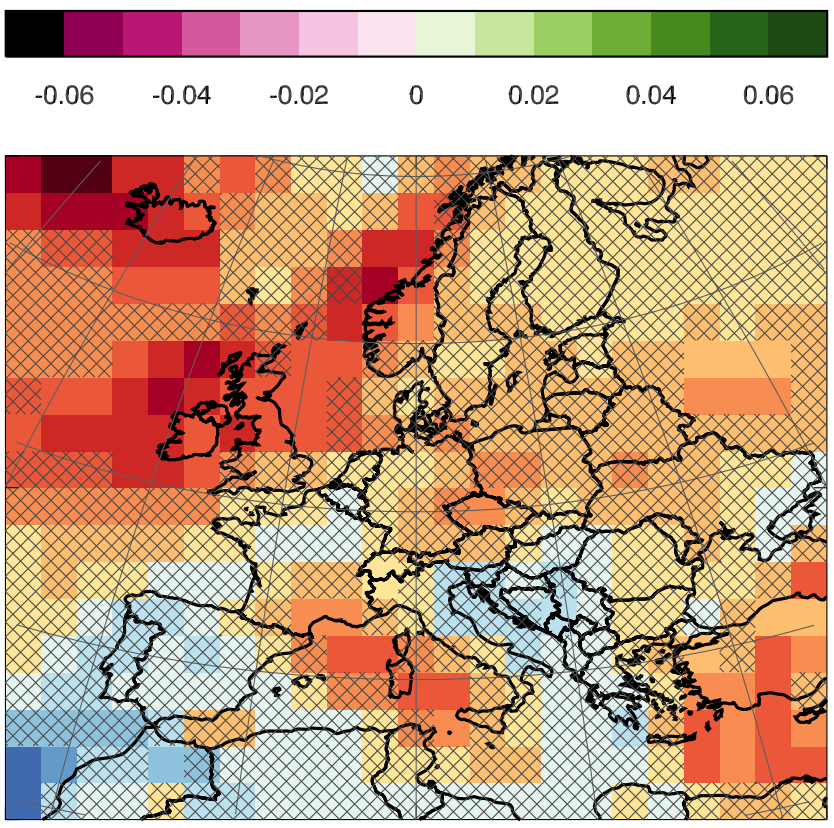

Linear trend in standard deviation of wind speed, $\mathrm{m} / \mathrm{s}$ per decade

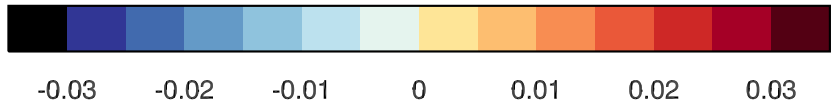

Fig. 9 Map of the linear trend in the time series of ensemble-annualmean wind speeds in each grid cell (top), and the ensemble-mean of the annual standard deviation of daily wind speeds (bottom), over 18712012. Crosshatched areas indicate where the trend is not significant at the $0.1 \%$ level (see text for details)

are only on the order of a few centimetres per second per decade; and secondly, that in most areas of the continent, the trend is not significantly different from zero. The trends in standard deviation show a similar spatial pattern, although at an even lower magnitude.
There are three areas of apparently significant trend in annual wind speed that merit looking at in more detail: the areas of positive trend in the Atlantic Ocean to the north and west of the British Isles, and the eastern Mediterranean around Crete; and the negative trend in an area of the central Mediterranean around the Italian peninsula and Sicily. The Mediterranean regions were also anomalous in terms of their bias with respect to ERA-Interim (see previous section). We look at the behaviour of wind speeds in these regions in more detail in Appendix C.

Bett et al. (2013) used the same significance threshold for analysing trends in the uncorrected 20CR data, but measured trends using simple linear regression and $t$ tests to establish significance. While we consider the present technique to be more robust, the magnitude and spatial patterns of the trends are similar, and similar regions are highlighted as significant, pointing to genuine features in the underlying 20CR data.

As already discussed in the context of the mean wind speed, it is important to realise that these trends are those seen at the large scales of the 20CR data, and detailed physical or statistical modelling is required to downscale to a specific location. Considering again the example of Kirchner-Bossi et al. (2013), they find that the site in Spain they describe has a statistically significant negative trend in wind speed of around $-0.01 \mathrm{~m} \mathrm{~s}^{-1}$ decade $^{-1}$. In our results, the corresponding grid cell has a trend of around $+0.01 \mathrm{~m} \mathrm{~s}^{-1} \mathrm{decade}^{-1}$, and is consistent with zero according to our test.

\subsection{Wind distribution time series}

We use a region covering England and Wales to to give an example of how wind speed distributions can vary with time. The time series of the area-averaged data from this region are shown in Fig. 10. The annual mean wind speed (panel a) shows both large interannual variability, and (when smoothed with a 5-year boxcar window) strong decadalscale variation. For example, the smoothed series shows a clear increasing trend from around 1970 to a peak in the mid-1990s, followed by a return to near-average values after 2000. When seen in the 142-year context however, these recent variations are not exceptional, and the yearto-year variability is always much greater. Note that, for this region, the year 2010 is the extreme low-wind year. This is linked to exceptionally cold months at the start and end of that calendar year, and a strongly negative NAO index in the 2009-2010 winter (Cattiaux et al. 2010; Osborn 2011; Brayshaw et al. 2012; Fereday et al. 2012; Maidens et al. 2013; Earl et al. 2013). The peak in wind speeds that occurs in the 1990s is another important feature in this region, and is also seen clearly in the observational record of wind speeds 
Fig. 10 Time series of the wind speed distribution for a region covering $5^{\circ} \mathrm{W}-1^{\circ} \mathrm{E}$ and $51^{\circ} \mathrm{N}-$ $55^{\circ} \mathrm{N}$. In panels a-c, annual statistics are shown in light colours/shading, with darker lines showing the data smoothed with a 5-year boxcar window. Panel a: Ensemble-mean annual mean wind speed. Individual years are shown with shading indicating the 10th/90th percentiles of the ensemble spread in the annual means. Panel b: Ensemble means of the deciles of the daily wind speed distribution each year (i.e. the 10th to 90th percentiles). Panel c: Distribution half-widths, i.e. half the difference between symmetric decile pairs (as labelled); the standard deviation $\sigma$ is also plotted, with its trend shown as a thin black dashed line. Panel d: The annual mean of the day-to-day standard deviation between ensemble members, as a fraction of the ensemble-mean annual mean wind speed

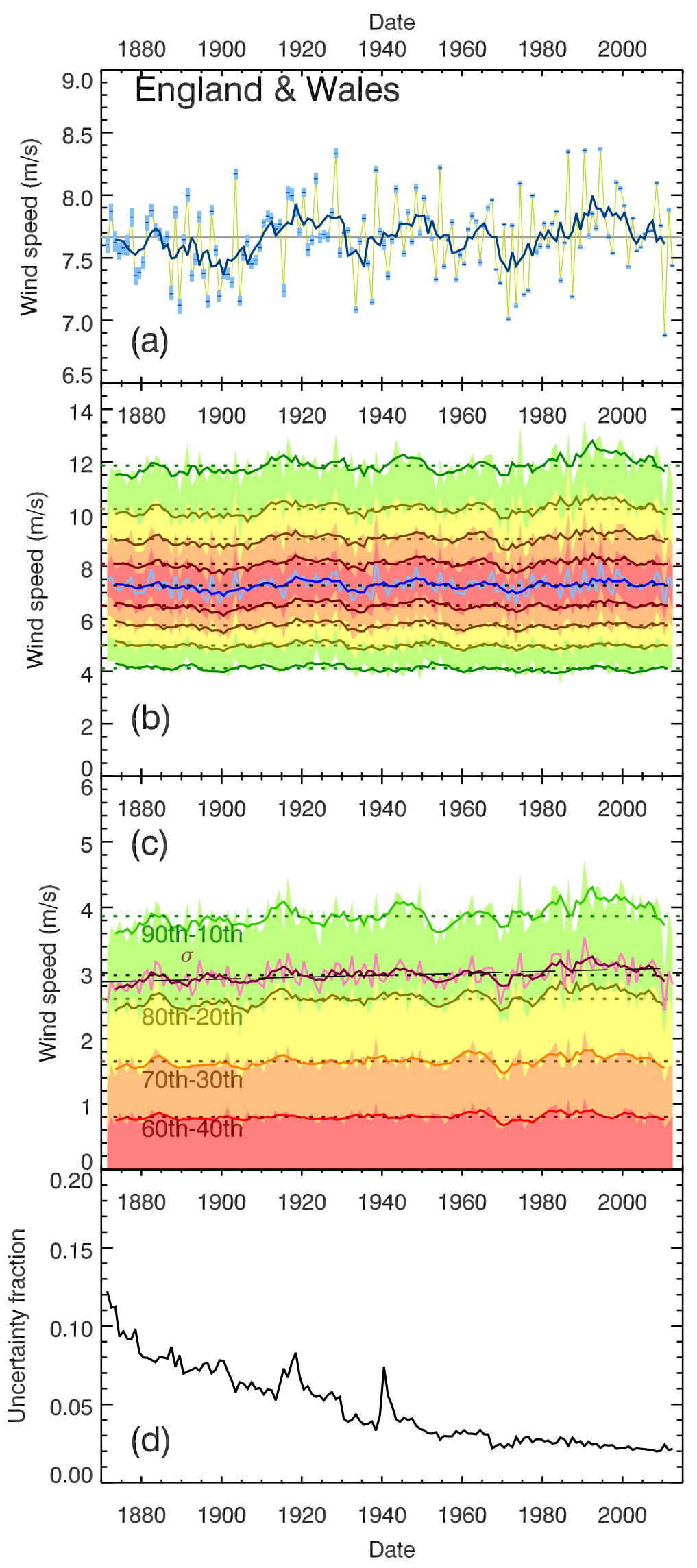


(Earl et al. 2013), in studies using geostrophic winds derived from pressure observations (Palutikof et al. 1992; Alexandersson et al. 2000; Wang et al. 2009), and is consistent with the large positive NAO in these years (e.g. Scaife et al. 2005, and references therein). Indeed, much of the variability of wind speeds in this region is likely to be related to modes of climate variability such as the NAO and Atlantic Multidecadal Oscillation (AMO, e.g. Knight 2006); further consideration of this requires careful seasonal breakdowns of both wind speed and these climate indices however, and is beyond the scope of this paper.

Our results bear a remarkable qualitative resemblance to those produced over 20 years ago by Palutikof et al. (1992) using geostrophic wind speeds (1881-1989) adjusted to match wind speed observations from a station in England over 1975-1984. A key purpose of that study was to illustrate the long-term variability present in wind speeds, as it could have important implications for wind power production. With the advent of larger datasets and greater computational capacity, we are able to reemphasize their conclusions and consider the decadalscale behaviour of the wind more robustly and in greater detail.

Considering the time series of the distribution as a whole (panel b), we can see that it follows the same decadal trends as the mean (panel a). The distribution width (panel c) highlights that while the outer reaches of the distribution are subject to much variability, with the distribution width growing and shrinking over decades, the inner parts of the distribution are much more constant. The standard deviation shown in that panel has a small but statistically significant positive trend, of $0.016 \mathrm{~m} \mathrm{~s}^{-1}$ decade $^{-1}$.

Finally, the bottom panel shows the relative uncertainty in the data, in terms of the annual mean of the day-to-day ensemble spread. As one looks further back, fewer observations are assimilated, and the ensemble members have more freedom to disagree with each other, resulting in increases in this measure of uncertainty. Two peaks are present that are related to the reduction in data from Atlantic shipping during the World Wars; these spikes in uncertainty are ubiquitous for near-Atlantic regions.

In Appendix C, we show similar plots for other regions that show particular features of interest, as already discussed.

Finally, we have given some consideration to the use of the Weibull (1951) distribution to concisely describe the wind speeds in our calibrated 20CR data. However, as already mentioned, our use of daily average wind speeds means that Weibull distributions tend to provide a poor description of the data. Nevertheless, the Weibull scale parameter, which is proportional to the mean of the distribution, does tend to behave in the same way as the mean wind speeds in terms of variability and trends. In particular, trends are of a similar magnitude and spatial pattern, and 'anomalous' regions in the central and eastern Mediterranean, noted in previous sections, are also present. Additional details and discussion are presented in the Supplementary Information.

\section{Discussion and summary}

In this paper, we have demonstrated how century-scale reanalyses - in particular, the Twentieth Century Reanalysis, 20CR - can be used for assessing the long-term trends and variability of near-surface wind speeds over Europe, through a calibration procedure to relate it to a higherresolution satellite-era climatology (such as ERA-Interim), and subsequent careful analysis.

The long baseline of the 20CR means that it has great potential to inform wind speed assessments for the wind energy industry. In general, reanalysis data is used in conjunction with dynamical and/or statistical downscaling techniques in order to reach the spatial scale of wind farms, as part of the 'model chain' in such assessments. Often, it is the observation-rich and relatively high-resolution data sets of ERA-Interim and MERRA that provide that first reanalysis step. This limits any assessment of long-term variability, since they both only cover $\sim 3$ decades. By calibrating the 20CR data to match the climatology of ERA-Interim over their period of overlap (1979-2012), this 142-year data set can be used in their place, providing a much more robust assessment of historic interannual and decadal variability in regions of Europe, and allowing the 'short-term' trends of the past 10-30 years to be put into the longer-term context.

To emphasise this point, we show in Fig. 11 the distribution of the 109 34-consecutive-year trends ${ }^{9}$ in annual mean wind speed for the England and Wales region described in the previous section. The full 1871-2012 trend is indicated and, as already shown, is near zero. The trend from ERAInterim for the 34 years of overlap is also marked, with a negative trend driven by the general reduction in wind speeds since the early 1990s. It is clear that the strong multidecadal variability in wind speeds means that attempting to estimate the long-term trend from a $\sim 30$-year sample can lead to misleading results.

The 20CR data is a rich source of information on the large decadal-scale variability of wind speeds. However, it is not without limitations, and hence it does need to be analysed with care. For example, in areas of complex orography, near-surface wind speeds are strongly reduced at the spatial scale of the 20CR, making their variability more difficult to interpret.

\footnotetext{
${ }_{9}$ i.e. the Thiel-Sen trend for 1871-1904 inclusive, and 1872-1905, 1873-1906, ..., and 1979-2012.
} 


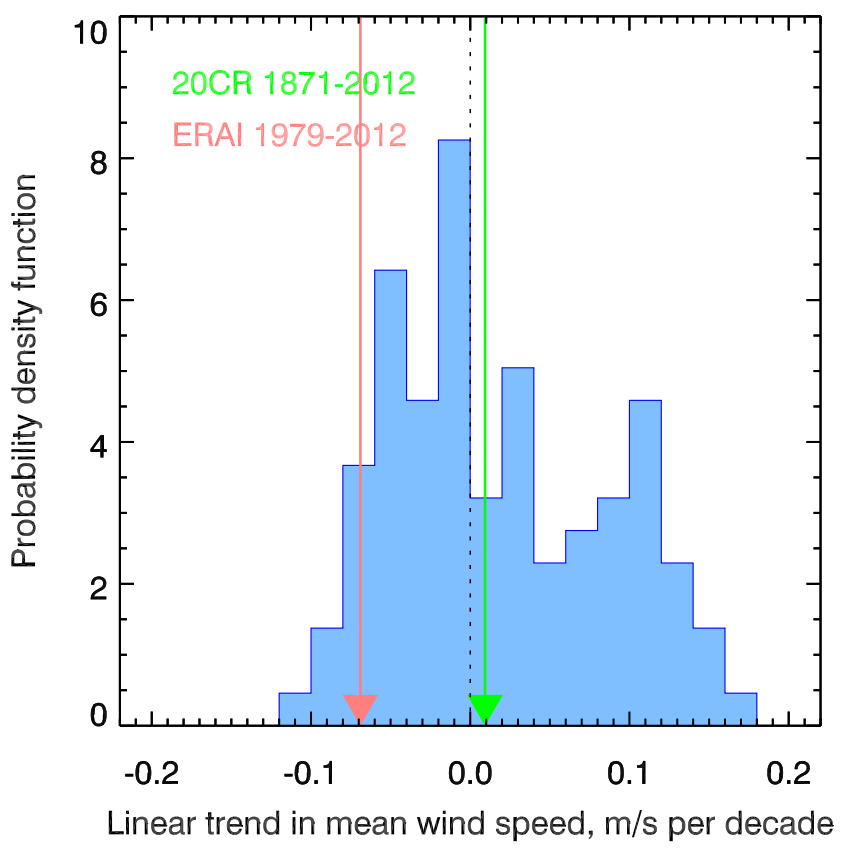

Fig. 11 Distribution of trends for the England and Wales region. The 34-year trends in annual-mean wind speeds from the calibrated 20CR data are shown as the blue histogram), overplotted with the full 142-year trend (green arrow). The single 34-year trend from the overlapping period of ERA-Interim is shown as a red arrow

As has been noted in other studies (Compo et al. 2011; Brönnimann et al. 2012), the ensemble nature of the 20CR needs to be taken into account when assessing long-term variability. Disagreement between ensemble members can be large, especially in the early period of the data. This leads to the daily ensemble-mean time series having less variability than the individual members, and can cause apparent trends in variability over time. Therefore, the daily ensemble-mean time series has little use in determining wind variability on long timescales, and the ensemble members should be used.

Assessment of trends over the full 142 years of the $20 \mathrm{CR}$ is complicated by the fact that the mid-point of the time series, and hence of a simple linear trend, is the 1940s. The reduction in ocean-based measurements during both the First and Second World Wars causes spikes in uncertainty, and in some cases systematic spikes in the wind speeds themselves (see Appendix C). Furthermore, the period after the Second World War corresponds to a large increase in national and international programmes collecting greater amounts of weather data. Taken together, the pre-1950s period is much more susceptible to greater random and systematic uncertainties. Measured trends in the 20CR data should therefore be treated with caution.

We have shown in fact that all trends in 20CR surface wind speeds over Europe are either consistent with zero (in most locations), so small to be of little practical relevance (e.g. possibly in the North Atlantic), or due to systematic problems with the data (e.g. in the central and eastern Mediterranean and possibly the North Atlantic; see Appendix C).

It is clear that, for most wind energy applications, interannual variability and the large decadal-scale variability are more important than the very small long-term trends in historical European wind speeds. Using century-scale reanalyses such as the 20CR allows wind resource assessment studies to incorporate more information on the historical decadal-scale variability at a site, which can reduce the uncertainties in the financial planning central to wind energy development.

Acknowledgments PB would like to thank Adam Scaife, Chris Folland, Clive Wilson, Malcolm Lee, Jess Standen, Alasdair Skea and Doug McNeall, and the anonymous reviewer, for helpful comments and discussion. Support for the Twentieth Century Reanalysis Project dataset is provided by the U.S. Department of Energy, Office of Science Innovative and Novel Computational Impact on Theory and Experiment (DOE INCITE) program, and Office of Biological and Environmental Research (BER) and by the National Oceanic and Atmospheric Administration Climate Program Office. ERAInterim data was obtained from the ECMWF archive and are used under license.

Open Access This article is distributed under the terms of the Creative Commons Attribution 4.0 International License (http://creativecommons.org/licenses/by/4.0/), which permits unrestricted use, distribution, and reproduction in any medium, provided you give appropriate credit to the original author(s) and the source, provide a link to the Creative Commons license, and indicate if changes were made.

\section{Appendix}

\section{A: Choice of vertical level}

In Fig. 12, we compare the daily mean wind speeds from 20CR at the $\sigma:=P / P_{\text {surface }}=0.995$ level with those at the other available near-surface levels of $P=1000 \mathrm{hPa}$ and $10 \mathrm{~m}$, over an arbitrary period. They have very similar variability behaviour, with the $1000 \mathrm{hPa}$ winds tending to be slightly higher, and the $10 \mathrm{~m}$ winds around $10-20 \%$ lower.

Figure 12 also includes 10 and $60 \mathrm{~m}$ winds from ERAInterim. The $60 \mathrm{~m}$ vertical level was chosen as it is roughly similar to the height expected at $P=0.995 P_{\text {surface }}$. A similar alternative would have been the $30 \mathrm{~m}$ model level, but we chose the higher level as it would be (marginally) less impacted by surface roughness; $60 \mathrm{~m}$ is also closer to wind turbine hub heights and thus more likely to be used for site-selection studies for the wind power industry. Figure 12 also suggests that the $60 \mathrm{~m}$ winds provide a fairly good match to the 20CR $\sigma=0.995$ winds by eye. 


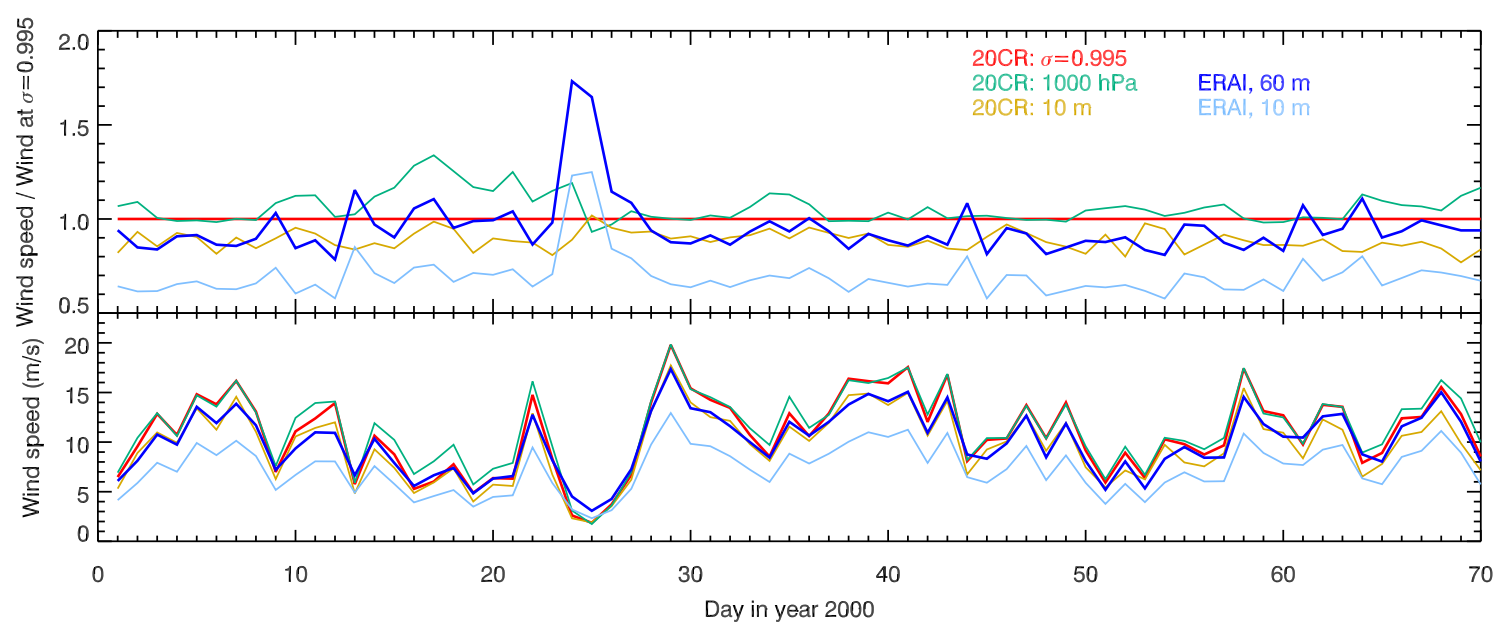

Fig. 12 Demonstration of the daily mean wind speed at different near-surface levels, for the England and Wales region. Both panels show the results from the ensemble-mean 20CR winds at the $\sigma=0.995$ level, at $1000 \mathrm{hPa}$, and at $10 \mathrm{~m}$, as well as

\section{B: Procedure for combining variances}

To avoid bias, we calculate variances of daily-mean wind speeds for each ensemble member separately, in consecutive $n$-year periods. In most cases, these periods are $n=5$ years, corresponding to the production streams of the 20CR (see Section 4.1); the final period has $n=2$ years, covering 2011 and 2012. These are combined into an aggregate population ${ }^{10}$ variance for the whole 142-year period over all ensemble members, using the following procedure.

If we consider a single time series of daily-mean wind speeds $U\left(t_{j}\right)$, at discrete timesteps labelled $j$, then we can divide it into a series of discrete $n$-year chunks labelled $i$, each containing $N_{i}$ days (leap years and the final 2-year period mean that not all $N_{i}$ are equal).

For each $n$-year period $i$, we can calculate the mean $\bar{U}_{i}=N_{i}^{-1} \sum_{j} U\left(t_{j}\right)$, the mean of squares $\bar{U}^{2}{ }_{i}=$ $N_{i}^{-1} \sum_{j} U_{j}^{2}$, and the variance $\sigma_{i}^{2}={\overline{U^{2}}}_{i}-\bar{U}_{i}^{2}$. We store the mean and variance for each $n$-year period, for each ensemble member.

The aggregate means over all $n$-year periods (i.e. the $142-$ year means in our case) are simply

$$
\begin{aligned}
\bar{U} & =\frac{\sum_{i} N_{i} \bar{U}_{i}}{\sum_{i} N_{i}}, \\
\overline{U^{2}} & =\frac{\sum_{i} N_{i} \overline{U^{2}}}{\sum_{i} N_{i}} .
\end{aligned}
$$

\footnotetext{
${ }^{10} \mathrm{We}$ use population statistics here rather than sample statistics because we use data from every day in each $n$-year period, rather than estimating the $n$-year standard deviation from a sample of days.
}

the 10 and $60 \mathrm{~m}$ winds from ERA-Interim after regridding to match 20CR. The top panel shows the daily-mean wind speeds as a ratio of the 20CR $\sigma=0.995$ wind, and the bottom panel shows the actual wind speeds

We can use these to write the aggregate population variance in terms of the mean and variance in each period:

$$
\begin{aligned}
\sigma^{2} & =\overline{U^{2}}-\bar{U}^{2} \\
& =\frac{\sum_{i} N_{i} \bar{U}^{2}}{\sum_{i} N_{i}}-\bar{U}^{2} \\
& =\frac{\sum_{i} N_{i}\left(\sigma_{i}^{2}+\bar{U}_{i}^{2}\right)}{\sum_{i} N_{i}}-\bar{U}^{2} .
\end{aligned}
$$

In practice, since we have stored the $n$-year means and variances for each ensemble member $m, \bar{U}_{i, m}$ and $\sigma_{i, m}^{2}$, we take ensemble means to obtain $\bar{U}_{i}$ and $\sigma_{i}^{2}$ for each period. These are then used to calculate $\bar{U}$ and $\sigma^{2}$ using Eq. 9.

\section{C: Additional regional time series}

In this section, we demonstrate the wind speed time series for some additional regions of interest, in the same manner as for the England and Wales results discussed in Section 4.2 (Fig. 10). The regions are defined in Table 1 and shown in Fig. 13, and were selected as areas of apparently 'significant' trends in wind speed (see Fig. 9). As elsewhere in this paper, trends are calculated using the Theil-Sen estimator, and their significance is tested using the modified Mann-Kendall test (see Section 4.1).

Figure 14 shows the results for the North Atlantic region. As well as having much stronger and more variable wind speeds overall compared to England and Wales, there are also significant positive trends in the annual mean wind speed and annual standard deviation of daily winds. The increase in the uncertainty prior to the 1940s is much more 
Table 1 Definitions of regions used in this study. Coordinates are given as $\left({ }^{\circ}\right.$ East, ${ }^{\circ}$ North). Results for the first two regions are given in the main body of this paper, and this Appendix describes the bottom three regions

\begin{tabular}{lrr}
\hline Name & SW point & NE point \\
\hline England and Wales & $-5^{\circ}, 51^{\circ}$ & $1^{\circ}, 55^{\circ}$ \\
Denmark and Northern Germany & $9^{\circ}, 53^{\circ}$ & $15^{\circ}, 57^{\circ}$ \\
North Atlantic & $-19^{\circ}, 49^{\circ}$ & $-13^{\circ}, 55^{\circ}$ \\
Sicily and Central Mediterranean & $11^{\circ}, 33^{\circ}$ & $17^{\circ}, 41^{\circ}$ \\
Crete and Eastern Mediterranean & $23^{\circ}, 33^{\circ}$ & $29^{\circ}, 37^{\circ}$ \\
\hline
\end{tabular}

striking than for the England and Wales region, and casts a degree of suspicion on the trend in the annual mean wind speed. It is plausible that the apparent trend is simply due the winds prior to the 1940s in this location being systematically slightly lower than in the subsequent period, rather than being due to any true underlying physical mechanism.

A possible cause - at least in part-could be a difference between the variance in the observations ingested by the reanalysis, and the preferred variance of the underlying NWP model. For example, if the observations are more variable than the model (e.g. if left running without assimilating data), then we might imagine that the 20CR data would have less variance at early times when there are much fewer observations. The skewed nature of wind speed distributions means that a trend in variance could lead to a trend in mean wind speeds too. However, the 20CR employs

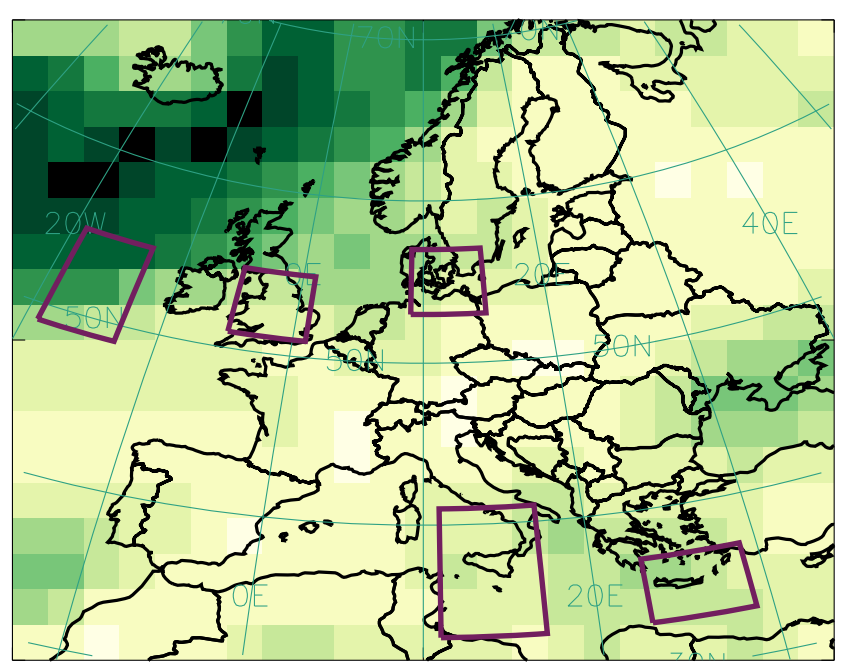

Mean wind speed, $\mathrm{m} \mathrm{s}^{-1}(2000 / 01 / 01)$

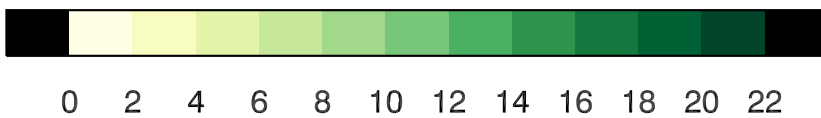

Fig. 13 Regions used in this study, overlaid on the mean wind speed from 20CR on an arbitrary day. The regions defined in Table 1 (on a regular lat-lon grid) are marked with boxes

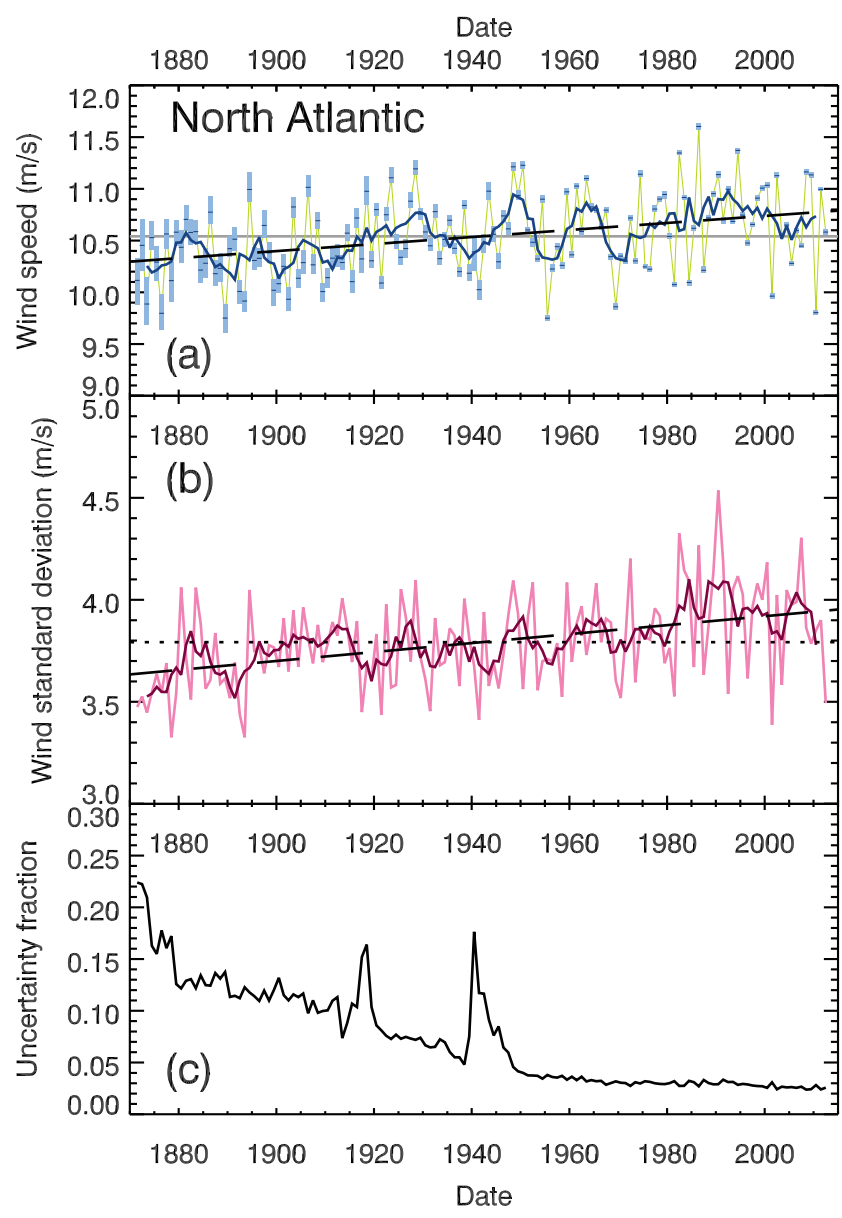

Fig. 14 Time series of the wind speed distribution for the North Atlantic region, following Fig. 10. The panels show annual values of mean wind speed (a), standard deviation of daily mean winds (b) and mean daily ensemble spread $(\mathbf{c})$. Dark lines in $(\mathbf{a}, \mathbf{b})$ give 5-year rolling averages, and trendlines are shown with black dashed lines; they are significant at the $0.1 \%$ level (see text for details)

a covariance inflation process (see Compo et al. 2011 and references therein for details), which will act in the opposite direction. Without further detailed study of the model behaviour, these ideas remain at the level of speculation.

The WASWind data set produced by Tokinaga and Xie (2011), based on ship-based measurements of wind and wave heights, has a negative trend in winds for the North Atlantic over 1950-2008. In our data, the trend over the 1950-2010 period is positive, but not significantly different from zero. The weakness of both trends, and difficulties with the observations in both cases, means that it is hard to be conclusive about the 'true' situation.

However, the negative trend we see between around 1990 to around 2005 is seen in the WASwind data, and Vautard et al. (2010) have shown that it is also present in the ERA-Interim data. Finally, Vautard et al. (2010) found a negligible trend in the North Atlantic in the NCEP/NCAR 
Reanalysis (Kalnay et al. 1996) over 1979-2008, which is also be consistent with our results.

Long-term trends in extreme wind speeds and storminess in the North Atlantic have been discussed in Wang et al. (2009, 2011, 2013), Krueger et al. (2013, 2014) and Wang et al. (2014). These studies relate extreme winds derived from long-term pressure records with those derived from the 20CR data set, and demonstrate both the decadal-scale variability that we see here, and the difficulty of drawing definitive conclusions from trend analysis with this data: different analysis methods can produce very different results, and the 20CR data prior to the 1950s should be treated both carefully and sceptically.

The Sicily and Central Mediterranean region appeared to have a significant negative trend in wind speeds in Fig. 9; the time series for the annual mean wind speeds in that region is shown in Fig. 15. We can see again the high levels of uncertainty prior to the 1950s, and a particularly anomalous spike in wind speeds around 1940-1942. If we take that spike to be indicative of the kind of systematic errors that might be present in the early half of the data, but not captured by the ensemble spread, then it is not unreasonable to suppose that the entire period prior to the 1940s could be showing higher wind speeds than it should, and thus accentuating a negative trend.

However, there does appear to be a more genuine negative trend in the data from the 1950s onwards, where the uncertainties are much more reasonable. We find that the Theil-Sen slope for the 1950-2012 period is very similar to that of the full 142 years, although in this case it is not significantly different from zero at the $0.1 \%$ level. However, as there are so few decades available from the 1950s, it is difficult to know how such an apparent trend relates to the decadal-scale oscillations that we see here, and in other regions.

Overall, the uncertainties in the data make it extremely difficult to separate decadal climate variability, systematic errors, and genuine long-term trend.

Pirazzoli and Tomasin (2003) looked at trends in the observed wind speeds over a similar region using station data mostly covering 1951-2000. They found a mixture of trend behaviours: most stations showed a negative trend prior to the 1970s that then became positive; some stations showed no trend, or trends which became negative from the 1970s onwards. In our data, which will not be able to resolve the complex coastal and orographic features of the region, we can see that the 5-year running mean appears to be increasing from the $1950 \mathrm{~s}$, changing to a negative trend after the 1970s. While this clearly disagrees with the Pirazzoli and Tomasin (2003) results from some stations, it is unclear how the variety of different observed behaviours in this complex terrain should combine to produce an aggregate trend on the large scales of the 20CR. In any case, the trends in the 20CR data are extremely slight; the main conclusion from our data should be that interannual variability is vastly more important than any trend for this region over a period as short as 50 years.

Finally, we show the time series for the Crete and Eastern Mediterranean region in Fig. 16. In this case, the apparent overall trend is positive. There is again a spike in wind speeds in the early 1940s, and a suggestion that the data prior to the 1950s could be systematically shifted relative to the latter period. Another interesting feature is that the early period until around the 1920s shows a slight decrease over time; if we exclude the 1940s spike, this then appears to be followed by a long generally-increasing period until the 1980s, after which the wind speeds have been relatively constant.

As before, the uncertainties in the data, both systematic and as seen in the ensemble spread, coupled with the expectation of decadal-scale variability and a time series that is 'only' 14 decades long, mean that it is impossible to know

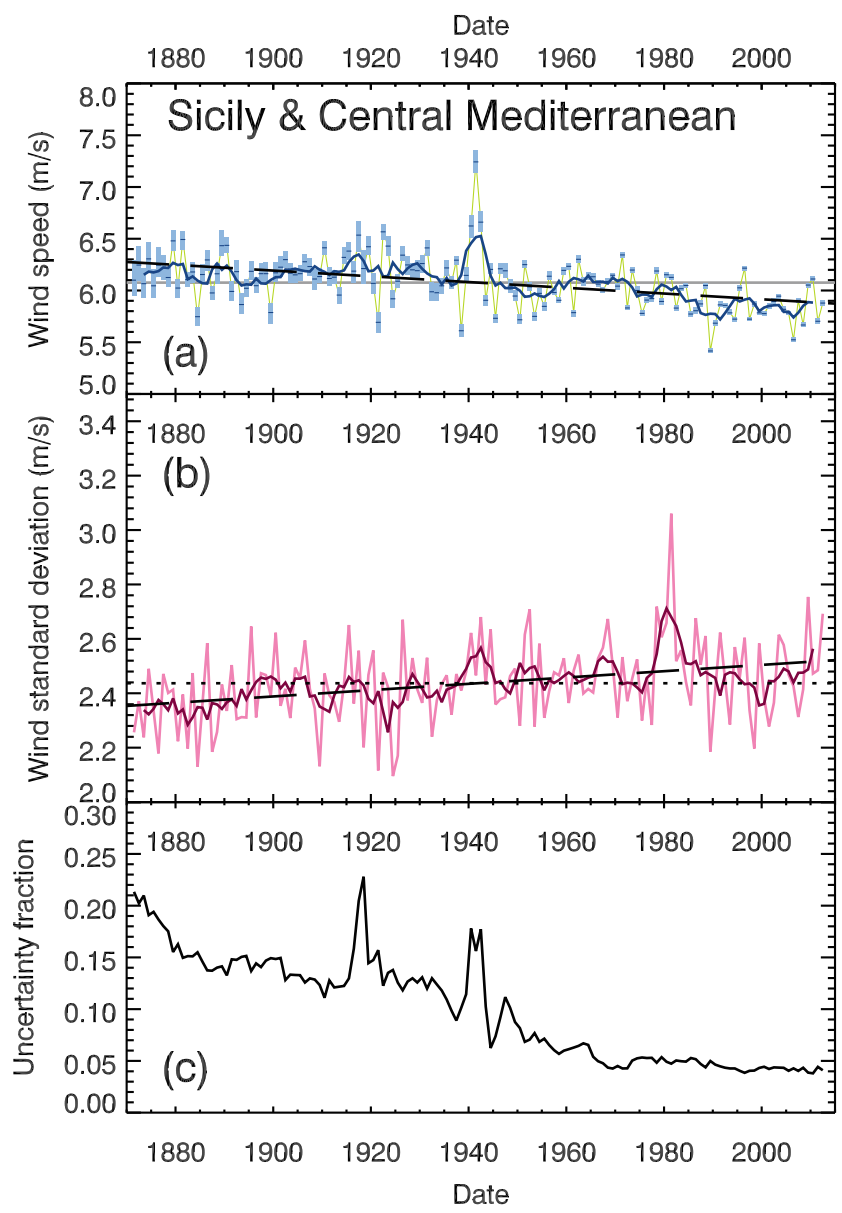

Fig. 15 As Fig. 14 but for the wind speed distribution in the Sicily and Central Mediterranean region. While the annual mean wind speeds have a significant negative trend (black dashed line in panel a, see text for details), there is no significant trend in the standard deviation (panel b) 


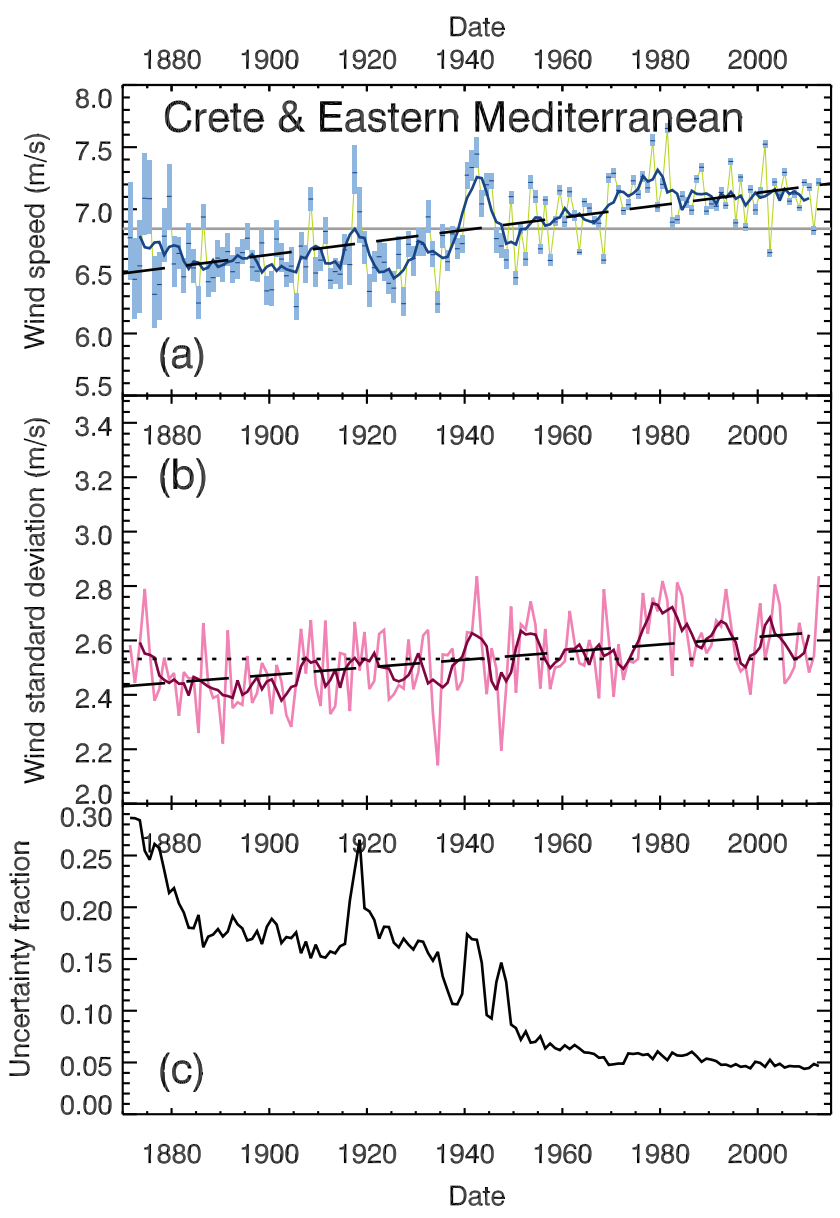

Fig. 16 As Fig. 14 but for the wind speed distribution for the Crete and Eastern Mediterranean region. Both the annual mean wind speeds (panel a) and the standard deviations (panel b) have statistically significant trends, marked as black dashed lines; see text for details

from this data alone how 'real' such a very long oscillation might be. If we allow for systematic shifts in the 1940s and before, the data is consistent with there being no long-term trend, but with decadal-scale variations underlying large interannual variability, as in other regions. What we can say with some certainty, however, is that the wind speeds in this region have been higher since the 1970s than they were in the 1950s and 1960s-with the caveat of there being strong interannual variability.

\section{References}

Alexandersson H, Tuomenvirta H, Schmith T, Iden K (2000) Trends of storms in NW Europe derived from an updated pressure data set. Climate Res 14:71-73. doi:10.3354/cr014071

Allan R, Brohan P, Compo GP, Stone R, Luterbacher J, Brönnimann S (2011) The international atmospheric circulation reconstructions over the earth (ACRE) initiative. Bull Am Meteorol Soc 92(11):1421-1425. doi:10.1175/2011BAMS3218.1
Annoni A, Luzet C, Gubler E, Ihde J (eds) (2003) Map Projections for Europe. Proceedings of the "Map Projections for Europe" workshop, Marne-La Vallee, 14-15 December 2000, EUR 20120 EN, Institute for Environment and Sustainability, European Commission Joint Research Centre, http://www.ec-gis.org/document.cfm? $\mathrm{id}=425 \& \mathrm{db}=$ document

Badger J, Frank H, Hahmann AN, Giebel G (2014) Wind climate estimation based on mesoscale and microscale modelling: statistical-dynamical downscaling for wind energy applications. J Appl Meteorol Clim 53(8):1901-1919. doi:10.1175/jamc-d-13-0147.1

Berrisford P, Dee D, Poli P, Brugge R, Fielding K, Fuentes M, Kållberg P, Kobayashi S, Uppala S, Simmons A (2011) The ERA-Interim archive. ERA Report Series 1, ECMWF, Shinfield Park, Reading, http://old.ecmwf.int/publications/library/do/ references/show?id=90276

Bett PE, Thornton HE, Clark RT (2013) European wind variability over 140 yr. Adv Sci Res 10:51-58. doi:10.5194/asr-10-51-2013

Bichet A, Wild M, Folini D, Schär C (2012) Causes for decadal variations of wind speed over land: sensitivity studies with a global climate model. Geophys Res Lett 39(11):L11,701+. doi:10.1029/2012GL051685

Boccard N (2009) Capacity factor of wind power realized values vs. estimates. Energy Policy 37(7):2679-2688. doi:10.1016/j.enpol.2009.02.046

Brayshaw DJ, Dent C, Zachary S (2012) Wind generation's contribution to supporting peak electricity demand-meteorological insights. Proc Inst Mech Eng O J Risk Reliab 226(1):44-50. doi:10.1177/1748006X11417503

Brönnimann S, Martius O, von Waldow H, Welker C, Luterbacher J, Compo GP, Sardeshmukh PD, Usbeck T (2012) Extreme winds at northern mid-latitudes since 1871. Meteorol Z 21(1):13-27. doi:10.1127/0941-2948/2012/0337

Carta JA, Velázquez S, Cabrera P (2013) A review of measurecorrelate-predict (MCP) methods used to estimate long-term wind characteristics at a target site. Renew Sust Energy Rev 27:362400. doi:10.1016/j.rser.2013.07.004

Cattiaux J, Vautard R, Cassou C, Yiou P, Masson-Delmotte V, Codron F (2010) Winter 2010 in Europe: a cold extreme in a warming climate. Geophys Res Lett 37(20):L20,704+. doi:10.1029/2010g1044613

Christensen J, Hewitson B, Busuioc A, Chen A, Gao X, Held I, Jones R, Kolli RK, Kwon WT, Laprise R, Rueda VM, Mearns, L, Menndez CG, Rsnen J, Rinke A, Sarr A, Whetton P (2007) Regional climate projections. In: Solomon S, Qin D, Manning M, Chen Z, Marquis M, Averyt K, Tignor M, Miller H (eds) Climate Change 2007: The Physical Science Basis. Contribution of Working Group I to the Fourth Assessment Report of the Intergovernmental Panel on Climate Change, Cambridge University Press, Cambridge, United Kingdom and New York, NY, USA., chap 11, http://www.ipcc.ch/publications_and_data/ ar4/wg1/en/contents.html

Christensen JH, Kumar KK, Aldrian E, An SI, Cavalcanti IFA, De Castro M, Dong W, Goswami P, Hall A, Kanyanga JK, Kitoh A, Kossin J, Lau NC, Renwick J, Stephenson D, Xie SP, Zhou T (2013) Climate Phenomena and their Relevance for Future Regional Climate Change. In: Stocker TF, Qin D, Plattner GK, Tignor M, Allen SK, Boschung J, Nauels A, Xia Y, Bex V, Midgley PM (eds) Climate Change 2013: The Physical Science Basis. Contribution of Working Group I to the Fifth Assessment Report of the Intergovernmental Panel on Climate Change (in press), Cambridge University Press, Cambridge, United Kingdom and New York, NY, USA., chap 14, doi:10.1017/CBO9781107415324.028, http://www.ipcc. ch/report/ar5/wg1/ 
Collins M, Knutti R, Arblaster JM, Dufresne JL, Fichefet T, Friedlingstein P, Gao X, Gutowski WJ, Johns T, Krinner G, Shongwe M, Tebaldi C, Weaver AJ, Wehner M (2013) Long-term Climate Change: Projections, Commitments and Irreversibility. In: Stocker TF, Qin D, Plattner GK, Tignor M, Allen SK, Boschung J, Nauels A, Xia Y, Bex V, Midgley PM (eds) Climate Change 2013: The Physical Science Basis. Contribution of Working Group I to the Fifth Assessment Report of the Intergovernmental Panel on Climate Change. Cambridge University Press, Cambridge, United Kingdom and New York, NY, USA., chap 12, pp 10291136. doi:10.1017/CBO9781107415324.024, http://www.ipcc.ch/ report/ar5/wg1/

Compo GP, Whitaker JS, Sardeshmukh PD, Matsui N, Allan RJ, Yin X, Gleason BE, Vose RS, Rutledge G, Bessemoulin P, Brönnimann S, Brunet M, Crouthamel RI, Grant AN, Groisman PY, Jones PD, Kruk MC, Kruger AC, Marshall GJ, Maugeri M, Mok HY, Nordli RossTF, Trigo RM, Wang XL, Woodruff SD, Worley SJ (2011) The Twentieth Century Reanalysis project. Q J R Meteor Soc 137(654):1-28. doi:10.1002/qj.776

Cradden LC, Harrison GP, Chick JP (2012) Will climate change impact on wind power development in the UK? Clim. Chang. 115(3-4):837-852. doi:10.1007/s10584-012-0486-5

Dee DP, Uppala SM, Simmons AJ, Berrisford P, Poli P, Kobayashi S, Andrae U, Balmaseda MA, Balsamo G, Bauer P, Bechtold P, Beljaars ACM, Van de Berg L, Bidlot J, Bormann N, Delsol C, Dragani R, Fuentes M, Geer AJ, Haimberger L, Healy, SB, Hersbach, H, Hólm EV, Isaksen L, Kållberg P, Köhler M, Matricardi M, McNally AP, Monge-Sanz BM, Morcrette JJ, Park BK, Peubey C, De Rosnay P, Tavolato C, Thépaut JN, Vitart F (2011) The ERA-Interim reanalysis: configuration and performance of the data assimilation system. Q J R Meteor Soc 137(656):553-597. doi:10.1002/qj.828

Dee DP, Balmaseda M, Balsamo G, Engelen R, Simmons AJ, Thépaut JN (2013) Toward a consistent reanalysis of the climate system. Bull Am Meteorol Soc 95(8):1235-1248. doi:10.1175/bams-d-13-00043.1

Dobrynin M, Murawsky J, Yang S (2012) Evolution of the global wind wave climate in CMIP5 experiments. Geophys Res Lett 39(18):L18,606. doi:10.1029/2012g1052843

Donat MG, Renggli D, Wild S, Alexander LV, Leckebusch GC, Ulbrich U (2011) Reanalysis suggests long-term upward trends in European storminess since 1871. Geophys Res Lett 38(14):L14,703+. doi:10.1029/2011g1047995

Earl N, Dorling S, Hewston R, Von Glasow R (2013) 1980-2010 variability in U.K. surface wind climate. J. Climate 26(4):1172-1191. doi:10.1175/jcli-d-12-00026.1

Fereday DR, Maidens A, Arribas A, Scaife AA, Knight JR (2012) Seasonal forecasts of northern hemisphere winter 2009/10. Environ Res Lett 034(3):031+. doi:10.1088/1748-9326/7/3/034031

Ferguson C, Villarini G (2014) An evaluation of the statistical homogeneity of the Twentieth Century Reanalysis. Clim Dynam 42(1112):2841-2866. doi:10.1007/s00382-013-1996-1

Ferguson CR, Villarini G (2012) Detecting inhomogeneities in the Twentieth Century Reanalysis over the central United States. J Geophys Res 117(D5):D05,123+. doi:10.1029/2011JD016988

Foley AM, Leahy PG, Marvuglia A, McKeogh EJ (2012) Current methods and advances in forecasting of wind power generation. Renew Energy 37(1):1-8. doi:10.1016/j.renene.2011.05.033

Folland CK, Knight J, Linderholm HW, Fereday D, Ineson S, Hurrell JW (2009) The summer North Atlantic Oscillation: past, present, and future. J Clim 22(5):1082-1103. doi:10.1175/2008jcli2459.1

Hamed KH, Rao AR (1998) A modified Mann-Kendall trend test for autocorrelated data. J Hydrol 204(1-4):182-196. doi:10.1016/s0022-1694(97)00125-x
Hartmann DL, Tank AMGK, Rusticucci M, Alexander LV, Brnnimann S, Charabi Y, Dentener FJ, Dlugokencky EJ, Easterling DR, Kaplan A, Soden BJ, Thorne PW, Wild M, Zhai PM (2013) Observations: Atmosphere and Surface. In: Stocker TF, Qin D, Plattner GK, Tignor M, Allen SK, Boschung J, Nauels A, Xia Y, Bex V, Midgley PM (eds) Climate Change 2013: The Physical Science Basis. Contribution of Working Group I to the Fifth Assessment Report of the Intergovernmental Panel on Climate Change. Cambridge University Press, Cambridge, United Kingdom and New York, NY, USA., chap 2, pp 159254. doi:10.1017/CBO9781107415324.008. http://www.ipcc.ch/ report/ar5/wg1/

Howard T, Clark P (2007) Correction and downscaling of NWP wind speed forecasts. Meteorol Appl 14(2):105-116. doi:10.1002/met.12

Hueging H, Haas R, Born K, Jacob D, Pinto JG (2012) Regional changes in wind energy potential over Europe using regional climate model ensemble projections. J Appl Meteorol Clim 52(4):903-917. doi:10.1175/JAMC-D-12-086.1

Hurrell JW, Kushnir Y, Ottersen G, Visbeck M (2003) An Overview of the North Atlantic Oscillation, Geophysical Monograph, vol 134, American Geophysical Union, Washington, D.C., chap 1, pp 135. doi:10.1029/134gm01, http://www.cgd.ucar.edu/staff/jhurrell/ naobook.html

Jung J, Broadwater RP (2014) Current status and future advances for wind speed and power forecasting. Renew Sust Energy Rev 31:762-777. doi:10.1016/j.rser.2013.12.054

Kalnay E, Kanamitsu M, Kistler R, Collins W, Deaven D, Gandin L, Iredell M, Saha S, White $G$, Woollen J, Zhu Y, Leetmaa A, Reynolds R, Chelliah M, Ebisuzaki W, Higgins W, Janowiak J, Mo KC, Ropelewski C, Wang J, Jenne R, Joseph D (1996) The NCEP/NCAR 40-year reanalysis project. Bull Am Meteorol Soc 77(3):437-471. doi:10.1175/1520-0477(1996)077<0437:TNYRP > 2.0.CO;2

Kendall MG (1975) Rank Correlation Methods, 4th. Charles Griffin \& Company, London

Kirchner-Bossi N, Prieto L, García-Herrera R, Carro-Calvo L, Salcedo-Sanz S (2013) Multi-decadal variability in a centennial reconstruction of daily wind. Appl. Energy 105:30-46. doi:10.1016/j.apenergy.2012.11.072

Kirchner-Bossi N, García-Herrera R, Prieto L, Trigo RM (2014) A long-term perspective of wind power output variability. Int $\mathrm{J}$ Climatol. doi:10.1002/joc.4161

Kiss P, Jánosi IM (2008) Comprehensive empirical analysis of ERA-40 surface wind speed distribution over Europe. Energy Convers Manag 49(8):2142-2151. doi:10.1016/j.enconman.2008.02.003

Kiss P, Varga L, Jánosi IM (2009) Comparison of wind power estimates from the ECMWF reanalyses with direct turbine measurements. J Renew Sustain Energy 033(3):105+. doi:10.1063/1.3153903

Knight JR, Folland CK, Scaife AA (2006) Climate impacts of the Atlantic multidecadal oscillation. Geophys Res Lett 33(17):L17,706+. doi:10.1029/2006g1026242

Krueger O, Schenk F, Feser F, Weisse R (2013) Inconsistencies between long-term trends in storminess derived from the 20CR reanalysis and observations. J Climate 26(3):868-874. doi:10.1175/jcli-d-12-00309.1

Krueger O, Feser F, Bärring L, Kaas E, Schmith T, Tuomenvirta $\mathrm{H}$, Storch H (2014) Trends and low frequency variability of extra-tropical cyclone activity in the ensemble of Twentieth Century Reanalysis by Xiaolan L. Wang, Y. Feng, G. P. Compo, V. R. Swail, F. W. Zwiers, R. J. Allan, and P. D. Sardeshmukh, Climate Dynamics, 2012. Clim Dynam 42(3-4):1127-1128. doi:10.1007/s00382-013-1814-9 
Kubik ML, Brayshaw DJ, Coker PJ, Barlow JF (2013) Exploring the role of reanalysis data in simulating regional wind generation variability over Northern Ireland. Renew Energy 57:558-561. doi:10.1016/j.renene.2013.02.012

Lafon T, Dadson S, Buys G, Prudhomme C (2013) Bias correction of daily precipitation simulated by a regional climate model: a comparison of methods. Int J Climatol 33(6):1367-1381. doi: $10.1002 /$ joc. 3518

Liléo S, Berge E, Undheim O, Klinkert R, Bredesen RE (2013) Longterm correction of wind measurements. state-of-the-art, guidelines and future work. Elforsk report 13:18, Elforsk, URL http://www. elforsk.se/Rapporter/?rid=13_18

Maidens A, Arribas A, Scaife AA, MacLachlan C, Peterson D, Knight J (2013) The influence of surface forcings on prediction of the north atlantic oscillation regime of winter 2010/11. Mon Weather Rev 141(11):3801-3813. doi:10.1175/mwr-d-13-00033.1

Mann HB (1945) Nonparametric tests against trend. Econometrica 13(3):245-259. http://www.jstor.org/stable/1907187

McVicar TR, Roderick ML, Donohue RJ, Li LT, Van Niel TG, Thomas A, Grieser J, Jhajharia D, Himri Y, Mahowald NM, Mescherskaya AV, Kruger AC, Rehman S, Dinpashoh Y (2012) Global review and synthesis of trends in observed terrestrial near-surface wind speeds: Implications for evaporation. J Hydrol 416-417:182-205. doi:10.1016/j.jhydrol.2011.10.024

McVicar TR, Vautard R, Thpaut JN, Berrisford P, Dunn RJH (2013) Land surface wind speed. In: Blunden J, Arndt DS (eds) State of the Climate in 2012, vol 94 (8), Bulletin American Meteorologia Society, chap 2, Global Climate, pp S27-S29, doi:10.1175/2013bamsstateoftheclimate. 1

Mears C (2013) Ocean surface wind speed. In: Blunden J, Arndt DS (eds) State of the Climate in 2012, vol 94 (8), Bulletin American Meteorologia Society, chap 2, Global Climate, p S29, doi:10.1175/2013bamsstateoftheclimate. 1

Meehl GA, Stocker TF, Collins WD, Friedlingstein P, Gaye AT, Gregory JM, Kitoh A, Knutti R, Murphy JM, Noda A, Raper SCB, Watterson IG, Weaver AJ, Zhao ZC (2007) Global climate projections. In: Solomon S, Qin D, Manning M, Chen Z, Marquis M, Averyt KB, Tignor M, Miller HL (eds) Climate Change 2007: The Physical Science Basis. Contribution of Working Group I to the Fourth Assessment Report of the Intergovernmental Panel on Climate Change, Cambridge University Press, Cambridge, United Kingdom and New York, NY, USA., chap 10, http://www.ipcc.ch/ publications_and_data/ar4/wg1/en/contents.html

Osborn TJ (2011) Winter 2009/2010 temperatures and a recordbreaking North Atlantic Oscillation index. Weather 66(1):19-21. doi:10.1002/wea. 660

Palutikof JP, Guo X, Halliday JA (1992) Climate variability and the UK wind resource. J Wind Eng Ind Aerod 39(1-3):243-249. doi:10.1016/0167-6105(92)90550-T

Panofsky HA, Brier GW (1968) Some Applications of Statistics to Meteorology. The Pennsylvania State University, University Park, Pennsylvania

Petersen EL, Troen I (2012) Wind conditions and resource assessment. WIREs Energy Environ 1(2):206-217. doi:10.1002/wene.4

Pirazzoli PA, Tomasin A (2003) Recent near-surface wind changes in the central Mediterranean and Adriatic areas. Int J Climatol 23(8):963-973. doi:10.1002/joc.925

Poli P, Hersbach H, Tan D, Dee D, JN Thpaut, Simmons A, Peubey C, Laloyaux P, Komori T, Berrisford P, Dragani R, Trmolet Y, Holm E, Bonavita M, Isaksen L, Fisher M (2013) The data assimilation system and initial performance evaluation of the ECMWF pilot reanalysis of the 20th-century assimilating surface observations only (ERA-20C). ERA Report Series 14, ECMWF, Shinfield Park, Reading, http://old.ecmwf.int/publications/library/ do/references/show?id=90833
Pryor SC, Barthelmie RJ (2010) Climate change impacts on wind energy: a review. Renew Sust Energy Rev 14(1):430-437. doi:10.1016/j.rser.2009.07.028

Pryor SC, Schoof JT (2010) Importance of the SRES in projections of climate change impacts on near-surface wind regimes. Meteorol Z 19(3):267-274. doi:10.1127/0941-2948/2010/0454

Rayner NA, Parker DE, Horton EB, Folland CK, Alexander LV, Rowell DP, Kent EC, Kaplan A (2003) Global analyses of sea surface temperature, sea ice, and night marine air temperature since the late nineteenth century. J. Geophys. Res 108(D14):4407+. doi:10.1029/2002JD002670

Rienecker MM, Suarez MJ, Gelaro R, Todling R, Bacmeister J, Liu E, Bosilovich MG, Schubert SD, Takacs L, Kim GK, Bloom S, Chen J, Collins D, Conaty A, da Silva A, Gu W, Joiner J, Koster RD, Lucchesi R, Molod A, Owens T, Pawson S, Pegion P, Redder, CR, Reichle R, Robertson FR, Ruddick AG, Sienkiewicz M, Woollen J (2011) MERRA: NASA's Modern-Era Retrospective Analysis for Research and Applications. J Clim 24(14):3624 3648. doi:10.1175/jcli-d-11-00015.1

Scaife AA, Knight JR, Vallis GK, Folland CK (2005) A stratospheric influence on the winter $\mathrm{NAO}$ and North Atlantic surface climate. Geophys Res Lett 32(18):L18,715+. doi:10.1029/2005GL023226

Scaife AA, Kucharski F, Folland CK, Kinter J, Brönnimann S, Fereday, D, Fischer AM, Grainger S, Jin EK, Kang IS, Knight JR, Kusunoki S, Lau NC, Nath MJ, Nakaegawa T, Pegion P, Schubert S, Sporyshev P, Syktus J, Yoon JH, Zeng N, Zhou T (2009) The CLIVAR C20C project: selected twentieth century climate events. Clim Dynam 33(5):603-614. doi:10.1007/s00382-008-0451-1

Sen PK (1968) Estimates of the regression coefficient based on Kendall's tau. J Am Stat Assoc 63(324):1379-1389. doi:10.1080/01621459.1968.10480934

Sousa PM, Trigo RM, Aizpurua P, Nieto R, Gimeno L, Garcia-Herrera $R$ (2011) Trends and extremes of drought indices throughout the 20th century in the Mediterranean. Nat Hazards Earth Syst Sci 11(1):33-51. doi:10.5194/nhess-11-33-2011

Stickler A, Brönnimann S (2011) Significant bias of the NCEP/NCAR and twentieth-century reanalyses relative to pilot balloon observations over the West African Monsoon region (1940-1957). Q J R Meteor Soc 137(659):1400-1416. doi: $10.1002 /$ qj. 854

Stopa JE, Cheung KF (2014) Intercomparison of wind and wave data from the ECMWF Reanalysis Interim and the NCEP Climate Forecast System Reanalysis. Ocean Model 75:65-83. doi:10.1016/j.ocemod.2013.12.006

Szczypta C, Calvet JC, Albergel C, Balsamo G, Boussetta S, Carrer D, Lafont S, Meurey C (2011) Verification of the new ECMWF ERA-Interim reanalysis over France. Earth Syst Sci 15(2):647666. doi:10.5194/hess-15-647-2011

Teutschbein C, Seibert J (2012) Bias correction of regional climate model simulations for hydrological climate-change impact studies: review and evaluation of different methods. J Hydrol 456-457:12-29. doi:10.1016/j.jhydrol.2012.05.052

Theil H (1950) A rank-invariant method of linear and polynomial regression analysis. In: Proceedings of Koninalijke Nederlandse Akademie van Weinenschatpen A, vol 53, pp 386-392. doi:10.1007/978-94-011-2546-8_20

Tokinaga H, Xie SP (2011) Wave- and Anemometer-Based Sea Surface Wind (WASWind) for climate change analysis. J Climate 24(1):267-285. doi:10.1175/2010jcli3789.1

Trenberth KE, Jones PD, Ambenje P, Bojariu R, Easterling D, Tank AK, Parker D, Rahimzadeh F, Renwick JA, Rusticucci M, Soden B, Zhai P (2007) Observations: Surface and atmospheric climate change. In: Solomon S, Qin D, Manning M, Chen Z, Marquis M, Averyt K, Tignor M, Miller H (eds) Climate Change 2007: The Physical Science Basis. Contribution of Working Group I to 
the Fourth Assessment Report of the Intergovernmental Panel on Climate Change, Cambridge University Press, Cambridge, United Kingdom and New York, NY, USA, chap 3., http://www.ipcc.ch/ publications_and_data/ar4/wg1/en/contents.html

Uppala SM, Kållberg PW, Simmons AJ, Andrae U, Bechtold FM, Gibson JK, Haseler J, Hernandez A, Kelly GA, Li X, Onogi K, Saarinen S, Sokka N, Allan RP, Andersson E, Arpe K, Balmaseda MA, Beljaars ACM, Berg BJ, Bormann N, Caires S, Chevallier F, Dethof A, Dragosavac M, Fisher M, Fuentes M, Hagemann S, Hólm E, Hoskins BJ, Isaksen L, Janssen PAEM, Jenne R, Mcnally AP, Mahfouf JF, Morcrette JJ, Rayner NA, Saunders RW, Simon P, Sterl A, Trenberth KE, Untch A, Vasiljevic D, Viterbo P, Woollen J (2005) The ERA-40 re-analysis. Q J R Meteor Soc 131(612):2961-3012. doi:10.1256/qj.04.176

Vautard R, Cattiaux J, Yiou P, Thepaut JN, Ciais P (2010) Northern hemisphere atmospheric stilling partly attributed to an increase in surface roughness. Nat Geosci 3(11):756-761. doi:10.1038/ngeo979

Wang XL, Zwiers FW, Swail VR, Feng Y (2009) Trends and variability of storminess in the Northeast Atlantic region, 1874-2007. Clim Dynam 33(7-8):1179-1195. doi:10.1007/s00382-008-0504-5

Wang, Wan H, Zwiers FW, Swail VR, Compo GP, Allan RJ, Vose RS, Jourdain S, Yin X (2011) Trends and low-frequency variability of storminess over western Europe, 1878-2007. Clim Dynam 37(1112):2355-2371. doi:10.1007/s00382-011-1107-0

Wang XL, Feng Y, Compo GP, Swail VR, Zwiers FW, Allan RJ, Sardeshmukh PD (2013) Trends and low frequency variability of extra-tropical cyclone activity in the ensemble of Twentieth Century Reanalysis. Clim Dynam 40(11-12):2775-2800. doi:10.1007/s00382-012-1450-9

Wang XL, Feng Y, Compo GP, Zwiers FW, Allan RJ, Swail VR, Sardeshmukh PD (2014) Is the storminess in the Twentieth Century Reanalysis really inconsistent with observations? a reply to the comment by Krueger et al. (2013b). Clim Dynam 42(34):1113-1125. doi:10.1007/s00382-013-1828-3

Watanabe S, Kanae S, Seto S, Yeh PJF, Hirabayashi Y, Oki T (2012) Intercomparison of bias-correction methods for monthly temperature and precipitation simulated by multiple climate models. J Geophys Res 117(D23):D23,114+. doi:10.1029/2012jd018192

Watson S (2014) Quantifying the variability of wind energy. WIREs Energy Environ 3(4):330-342. doi:10.1002/wene.95

Weibull W (1951) A statistical distribution function of wide applicability. J Appl Mech 18(3):293-297

Wentz FJ, Ricciardulli L (2011) Comment on Global trends in wind speed and wave height. Science 334(6058):905. doi:10.1126/science. 1210317

Wever N (2012) Quantifying trends in surface roughness and the effect on surface wind speed observations. J Geophys Res 117(D11):D11,104+. doi:10.1029/2011JD017118

Wiser R, Yang Z, Hand M, Hohmeyer O, Infield D, Jensen PH, Nikolaev V, O'Malley M, Sinden G, Zervos A, Von Stechow C (2011) Wind energy. In: Edenhofer O, Pichs-Madruga R, Sokona Y, Seyboth K, Matschoss P, Kadner S, Zwickel T, Eickemeier P, Hansen G, Schlömer S (eds) IPCC Special Report on Renewable Energy Sources and Climate Change Mitigation, Cambridge University Press, Cambridge, United Kingdom and New York, NY, USA, chap 7., http://srren.ipcc-wg3.de/report/

Young IR, Zieger S, Babanin AV (2011a) Global trends in wind speed and wave height. Science 332(6028):451-455. doi:10.1126/science.1197219

Young IR, Babanin AV, Zieger S (2011b) Response to comment on global trends in wind speed and wave height. Science 334(6058):905. doi:10.1126/science. 1210548

Young IR, Vinoth J, Zieger S, Babanin AV (2012) Investigation of trends in extreme value wave height and wind speed. J Geophys Res 117(C11):C00J06. doi:10.1029/2011jc007753 